\title{
HET AANHANGIGE ONTWERP TOT WIJZIGING DER WET OP DEN VERKOOP VAN STERKEN DRANK IN HET KLEIN. ${ }^{1)}$
}

Het is moeilijk een eer te weigeren van iemand, dien men eert. Ik ben noch econoom, noch jurist, noch volksvertegenwoordiger, noch bezit ik eenige andere qualificatie om mede te spreken over een der onderwerpen ann welker bespreking dit tijdschrift is gewijd, en het in den titel vermelde ouderwerp maakt daarop geen uitzondering. Ik heb alle mogelijke redeu om te verwaehten, dat menig jurist, en menig econoom, zal meesmuilen, lachen of toornen over de leeken-beschouwingeu, die in dit stuk ten beste zullen worden gegeven.

De geachte Redactie van dit geëerde tijdschrift wist dit alles ook wel, toen zij uitdrukkelijk van mijne hand een artikel over het aanhangig ontwerp tot herziening der drankwet verlangde. Ik moet dus aanuemen, dat zij het gewild heeft, dus, dat zij er haar goede redenen voor had, en daarom ben ik uit eerbied voor haar voor haar aandrang gezwicht.

Loochenen kan ik niet, dat ik vroeger verscheidene jaren lang in de voorste rijen der geheelonthouders heb meegestredeu, en dat nog en met volle overtuigeng zou doen, wanneer ambtelijke bezigheden en positie mij nog gelegenheid lieten voor opeubaren propaganda-arbeid. Vermoedelijk moet dus damin mijne ontbrekende qualificatie gezocht worden.

Maar dan dient toch terstond, ter vermijding van alle mis-

1) Dit artikel was reeds geschreven vóor het verschijnen van het Voorloopig Verslag. Tot omwerking geeft dit geen aanleiding, al was daarvoor nog gelegenheid, terwijl de wijze, waarop het in de kleinste bizonderheden afdaalt, 't onmogelijk maakt om door' enkele inlasschingen of bijgevoegde noten er rekening mede te houden. 
verstand, opgemerkt, dat ik als zoodanig het vraagstuk altijd slechts van den zedelijken kant heb beschouwd. Zeker, ik heb op mijn manier wel eenige studie gemaakt van het drankvraagstuk en darrbij ook wel kennis genomen van wat juristen, staathuishoudkundigen en medici daarover hebbeu geschreven. Maar ik heb mij altijd principieel onthouden van beunhazen op velden van wetenschappelijke studie, die de mijue niet waren, En ik kon dit te gereeder doen, omdat voor mij het drankvraagstuk ten slotte toch altijl is en. blijft een zedelijk vraagstuk, elı, ik denk, voor de meesten onzer.

Maar dan keert wederom de vrang terug: is de behandeling van dit vraagstuk onder dit gezichtspunt op haar plaats in dit blad?

Of moet de uitnoodiging van de Redactie zóó worden opgevat, dat zij daarmede te kennen wil geven, dat economische vragstukken ook een ethischen kant hebben, die niet verwaarloosi mag worden; en dat met uame een wettelijke maatregel, die zoo diep ingrijpt in het volksleven als de beteugeling der drinkgewoonten, niet zuiver kan beoordeeld worden, teuzij de juridische en economische deskundigen ook het oor leenen aan wat een ethisch denkend leek daarover te zeggen heeft?

In dat geval: accipio omen.

Fn nog in een ander opzicht doe ik dit, en met groote vreugide. Ik zie namelijk in cle an mij verstrekte opdracht een soort van openlijk getnigschrift, door bevoegde en hoogstnande beoordeelaars uitgereikt, dat een geheelonthouder geenszins per se een fanaticus is, buiten staat om een mantschappelijk of zedelijk vraagstuk met een koel. hoofd te beoordeelen, en met wien niet te redeneeren valt. Mogen de hierma volgende beschouwingen dat goede getuigenis niet te schande maken.

Intusschen, hoe men zich drait of keert, in een tijdschrift als de Economist kan men niet uitsluitend toe met ethische beschouwingen. Ik heb daarom, met goedvinden der Redactie, de hulp ingeroepen van een bij uitstek bevoegde, vau mijn vriend en geestverwant den heer Th. W, van der Woude, den uitnemend deskundigen Redacteur van het Tijdschrift "De Wegwijzer" (Uitgave S. L. van Looy), dat ik bij deze gelegenheid met warmte anbeveel, daar het nog veel abounés te kort komt en alleszius steuu verdient, omdat het, 
wat de taak van zulk een tijdschrift moet zijn: zijn lezers op de hoogte houden van het onderwerp, op een boven mijn lof verheven wijze vervult. Deze heer, die een jarenlange studie van het drankvraagstuk in zijn vollen omvang heeft gemakkt, heeft mij den gevraagden bijstand niet onthouden, en wat er zakelijk goeds in mijn artikel is, daarvoor zijn mijne lezers en ik.hem dank verschuldigd.

Hierdoor is er teveins voor gezorgd, dat deze beschouwingen in overeenstemming zijn met de wenschen en inzichten van het Uitvoerend Drankwetcomité, waarbij zich tot nog toe alle drankbestrijders in den lande hebben aangesloten (behalve natunrlijk de principieele tegenstanders van alle wettelijk ingrijpen op dit gebied), van welk Comité de heer van der Wonde Secretaris en de ondergeteekeude lid is. )

\section{DE OPPOST'TE 'WGEEN HWI WU'ISON'TWTRP.}

Toen bovengemeld verzoek tot mij $\mathrm{kwam}$ en door mij werd aangenomen, was de actie voor het wetsontwerp reeds in vollen gang. Drankbestrijders van allerlei kleur hadden zich opgemakkt om de Regeering te steumen en bij de Kamer op de urgentie aan te dringen. Hetzij hierdoor, hetzij om andere redenen, de Kamer heeft, schoon overstelpt met bezigheden, het ontwerp reeds in de afdeelingeu onderzocht en de openbare behandeling kan eerlang tegemoet gezien worden.

Maar sedert is ook een andere actie losgekomen, ditmaal vil

1) De overige leden zijn P. van dur Meulen, Voorzitter, Ds. W. H. Gispen Jr., G. J. Jansonius, Mr. R. B. Ledeboer; Jhr. Mr. Ch. Ruys de Beerenbrouck. Zie: Onze Wenschen voor do aanstaande drankwetsherziening, uitgegeven door het Uitvoerend Drankwetcomité, te ontbieden' bij G. J. Jansonitus te Drachten. De "Volksbond" benoemde een eigen Commissie, die in denzelfden geest werkt. Zij bestaat uit Mr. F. W. J. G. Snijder van Wissekerke en Mr. van Gijn, President en Seoretaris q.q. Dr. A. Ariëns, Mr. J. Bool, W. G. A. H. van Berkel, Mr. H. Goeman Borgesius, W. C. van Haeften, Dr. Th. aen Houter, S. Lulofs, Prof. Dr. C. A. Pekelharing, Dr. W. P. Ruysch, J. H. A. Schaper, Prof. Mr. D. Simons, A. van der Voort Azn., L. P. Walburgh Schmidt en A. L. Wolters. Haar adres met toelichting vindt men in het Novembernummer van "De Volksbond”, het orgaan der gelijknamige, vereeniging (Slothouwer, Amersfoort).

Econ. 1904. 
de tegenstanders van het ontwerp en zij gaat nog onverzwakt voort.

Moet men haar belangrijkheid afmeten naar het aantal der door haar gehouden vergaderingen en de vlakke inhoud van het door haar volgeschreven papier, dan wint zij het verre. Eerst was het mijn voornemen, in dit stnk een overzicht te geven en eel weerlegging te beproeven van hunne argumenten, maar de eindeloos wassende stroom heeft mij noodzakelijkerwijze dit voornemen doen opgeven. Het is ook beter zoo; wij kunnen nu de zaak uitsluitend principieel beschouwen.

Want in al die adressen en protestvergaderingen klinkt één toon: "onze particuliere belangen worden geschnad".

Dat liedje hebben we al meer gehoord.

Maar de vorige maal klonk het toch anders. Toen het outwerp-Borgesius aanhangig was gemaakt, dat toch veel mindes scherp was, hebben de drankverkoopers een jurist in hum dienst genomen, die zijn pen leende om te betoogen, dat de invoering van drankwetten het drankgebruik niet alleen niet deed verminderen, maar juist deed toenemen. Met de stukken kon toen worden aangetoond, dat dit resultant alleen verkregen was door een gansčh eigenaardige bewerking van te statistieke gegevens ').

Thans, nu de Regeering er het mes dieper wil inzetten, wordt die toon wel niet geheel gemist - zoo betoogen de wijnhandelaren, dat zij eigenlijk bestrijders van het drankverbruik zijn en dus door de voorgestelde bepalingen gansch onnoodig en onbillijk in hun bedrijf belemmerd worden - manr in het algemeen komt men er rouder voor uit, dat het 't bedreigde eigenbelang is, dat spreken doet. En dat dit wel in start is indruk te maken, blijkt o. a. uit het feit, dat eè zoo aamzieulijk blad als het Handelsblad er een reporter op uitzond, om te gaan vernemeu. "wat de belanghebbenden er van dachten". Is dat uiet bij den duivel te biecht gaan? ${ }^{2}$ )

1) Zie: Mr. W. A. PAar. Het dogma der Drankwet. W. Versluys, Amsterdam. - TH. W. vaN ner Woobe. Het dogma van $\mathrm{Mr}$. Paap, in "De Wegwijzer" Jig. IV. S. L. van Looy. Amsterdam.

2 En daarom lijkt mij de enquête van het Handelsblad, hoe goed bedoeld wellicht ook, in dit geval al heel ongelukkig bedacht en gevaarlijk ook. 
"Ja, maar mag dan cen algemeene wet particuliere belangen schaden?"

Mij dunkt, dat is geen vraag. Iedere wet doet dit. Iedere wet bekort op de een of andere wijze particnliere vrijheden ten behoeve van het algemeen belang, tast dus het een of auder particulier belang aan.

De vrag is slechts, of de particuliere belangen, die geschaad worden, ruimschoots worden opgewogen door de algemeene, die er door worden gebaat. Wordt die vrang tot aller genoegen in bevestigenden zin beantwoord, dau aarzelt men niet zelfs het meest eervolle bedrijf ann banden te leggen en daarmede tal vau particuliere belangen te kwetsen. Geen duidelijker voorbeeld dan het onderwijs. Zelfs de vurigste voorstander vau de "vrijmaking wan het ouderwijs" denkt ex niet aau (misschieu op een enkele stem des roependen in de woestijn ua) te verlangen, dat de staat afstand due van zijn toezicht, van de waarborgen die hij eischt van ouderwijzers en onderwijs. Eu toch, men denke het slechts even in, is er krasser beteugeling der particuliere vrijheid, is er gevoeliger beuadeeling van particuliere belangen denkbaâr, dan door de staatsvoogdij over het onderwijs? Ik denk daarbij nog niet eens aan geldelijke belaugen; maar hoeveel geboren onderwijzers worden door al die wettelijke waarborgen van het onderwijs geweerd om vervangen te worden door min of meer kunstmatig opgekweekte middelmatigheden, tot groot ongerief van ouders en kinderen en tot niet geringe schade der gemeenschap zelve, die aldus van vele uitnemende onderwijskrachten beroofd wordt? En toch is ieder overtuigd, eeu eeuwenlange ondervinding heeft het geleerd, dat die staatscontrôle en die stantswaarborgen eenvoudig onmisbaar zijn, zoodat men hun nadeeleu op den koop toe moet uemen. En zoozeer is men daaraan reeds gewend, dat weinigen zich van die nadeelen rekenschap geven: de groote menigte beseft ze niet.

Indien men nu dit doet ann het groeue hout, wat zal aan het dorre geschieden? Wanneer de wet zelfs het zoo eervol en heilig beroep van onderwijzer niet ontziet, zal zij din complimenten maken met dat van kroegbazen en slijters? Kan het één oogenblik voor iemand twijfelachtig zijn, naar welke zijde de balans omslant, naar de zijde van de. enkele duizendeu die 
geldelijk belang hebben bij den drankhandel in eenigen vorm, of naar de zijde der gansche natie, die een intens financieel, hygienisch en moreel belang heeft bij een sterke inkrimping daarvan?

Wij weten, dat de vraag zoo eenvoudig niet is, al zouden vurige drankbestrijders haar gaarue tot zoo eenvoudige proportiën willen herleiden. De moeilijkheid, of liever de moeilijkheden, schuilen daarin, dat de appreciaties van het bedrijf dergenen, die hun belangen door de bestaande drankwet en nog meer door de voorgestelde verscherping ervan bedreigd achten, uog zoo uiteenloopen, en dat dit bij den huidigen toestrnd der maatschappij en bij de heerschende opvattingen niet anders kan ziju. .

De Regeering zegt wel zelve, bl. 12 der Memorie van Toeliehting: "In steeds ruimer wordende kringen vat de overtuiging post, dat het bedrijf van tapper aan ernstige zedelijke bezwaren onderhevig is: de wetgever zelf geeft blijk, die bezwaren te gevoelen en hij zou het zelfs moeten toejuichen, indien die overtuiging door allen gedeeld werd. Hij heeft daarom het recht, is zelts verplicht, te vorderen, dat wie uit dit bedrijf tot zedelijke en stoffelijke schade van een overgroot deel der samenleving winst trekt, daarvan zelfs bestant, openlijk bekend zij." Maar, behalve dat hier expressis verbis erkend wordt, dat deze overtuiging vooralsnog niet algemeen is, en er zeker onder de drankverkoopers nog wel zijn, die haar met een gerust geweten verwerpen, zoo slaat dit hoogstens alleén op hen, die van den verkoop van sterken drank hun éénig bedrijf maken. De moeilijkheid zit echter juist daarin, dat er zoovele bedrijven ziju, die de samenleving nog geenszins missen kan, die in uiemands oog met "infamia" besmet zijn, en die met drankverkoop zijn gemengd. Waarbij nog komt, dat deye belanghebbenden met kracht en klem betoogen, dat de voorgestelde maatregelen uitsluitend zullen ten gevolge hebbeu, dat zij in hun geldelijke belangen worden getroffen, z o n d e r d a t de zrak der drankbestrijding er iets door worde bevorderd, eerder het tegendeel.

Misschien kumnen de volgende overwegingen iets, al is het ook niet veel, bijdragen, tot opheldering. Beginnen wij met de laatste tegenwerping, die verreweg de belangrijkste is.

Daaromtrent moet wordeu opgemerkt, dat dit alles toekomst- 
muziek is: Wanneer men de hierop doelende beweringen der bestrijders van het ontwerp leest en herleest, dnn moet men bekennen, eensdeels, dat v e el van wat zij voorspellen, mog elijk, anderdeels, dat niets er van bewezen is. En meer, dat ook niets ervan bewijsbaar is. Al worden zij op nog zoo stelligen toon voorgedragen, al bekleeden hun profeten zich nog zoozeer met het gezag van persoonlijke en ambtelijke ervaring, hun voorspellingen blijven voorspellingen, dat is gissingen. De uitkomst hangt niet alleen af van de factoren, die zij in het geding brengen, mar ook van andere, waarover zij hoegenaamd niets te zeggen hebben en waarvan zij weinig afweten: Nemen, wij de meest specieuse van al hun bedenkingen. Zij rekenen ons voor, dat door de voorgestelde maatregelen het drankverbruik zich op groote schal zal verplaatsen van de kroeg nnar het gezin, waardoor het niet alleen zal toenemen, maar ook nog veel gevaarlijker karakter zal aannemen. Ik zal niet zeggen, dat dit een losse bewering is, maar ik vraig: waar is het bewijs? Laat ons gannemen, wat inderdaad aannemelijk is, dat dit in sommige gezinnen het geval zal zijn; volgt daaruit dat het regel zal zijn? Hangt dit niet, zoo niet geheel, dan toch bijna geheel, af van het zedelijk weerstandsvermogen, van het zedelijk peil en gehalte, van de zedelijke opvattingen en maatschappelijke gewoonten van de betrokken gezinnen? En wie nu, die eenigszins op de hoogte is van de verauderingen in zeden en opvattingen, die ook in arbeiderskringen, ja vooral in dezen, in de laatste 10,20 jaren met betrekking tot het drankgebrnik hebben plaats gegrepen, zal zich zoo maar klakkeloos laten anpraten, dat de Nederlandsche werkman, wanneer hem de gang naar de kroeg zooveel moeielijker wordt gemaakt, dan maar thuis zal gaan zitten drinken en vrouw en kinderen ook aan het drinken zal zetten? Wie voelt niet iets ran den hoon; die daardoor, zij het ook onbedoeld, onzen ontwikkelden werklieden wordt angedaan? Hoe wordt darbij de invloed van moeder de vrouw, en van heel de huiselijke atmosfeer, miskend en weggecijferd? Hoe wordt niet door zulke beweringen de warrheid in het aangezicht geslagen, dat de gelegeuheid den dief maakt, en, voegen wij er bij, niet minder het voorbeeld en de verleiding? Ware het ten deze anders, warom wordt dan door i edereen het voorstel toegejuicht om 
het nitbetalen van loonen in kroegen te verbieden? Findelijk : waar rleukt mell, dat wij, drankbestrijders, liever den strijd tegen onzen volksvijand \%ulleu aanbinden, in de kroeg of in het gezin?

Iu dezen stand vau zaken zullen de belanghebbenden het zich moeten getroosten, dat men hun sombere voorspellingen, juist omclat zij van belanghebbenden komen, als verdacht afwijst. $\mathrm{Nn}$ zij het grif erkend, dat ook dezerzijds slechts waarschijnlijkheidsgrouden kunnen worden angevoerd, maar die kunnen ten minste worden anugevoerd, terwijl men ons van de andere zijcle met bloote voorspellingen afscheept.

Verder bedenke men dit: de personen kunnen, en moeten, buiten spel gelateu worden. Wij willen, zelfs trots de Regeering, aainemen, dat er nog vele eerzame kroeghouders zijn, even eerzaam als de meest fatsoenlijke logement- of koffiehuishouder. Wij willen de Regeering er an herinmeren, dat de wetgever niet tegen hen mag ageereu, hetzij dan dat hij ze uitdrukkelijk als misdadigers bestempele. Maar de wet doet dat ook niet; niet op de verkoo pers als zoodanig heeft zij het gemunt, maar op het cloor hen verkochte product. Dat dit product schadelijk eu gevaarlijk is, voor individueu zoowel als voor heele lagen der bevolking, ja voor de gausche natie (wij willen ons voorrichtig uitdrukken eu er dus bijvoegen: behoudens onder zekere voorwarden,) ja, dat is nu eenmaal bewezen, en op grond daarviu heeft de natie nu reeds twintig jaar geleden bepaald, dat de verkoop van dit product niet vrij mocht zijn. Wie het verkoopen wil, kan het niet doen, slechts aan enkelen zal het; worden toegestan, en dan alleen onder zekere voorwaarden. Door de bestande drankwet zij a de drankverkoopers reeds buiten het gemeene recht geplaatst.

Of die voorwarden un ua twintig jaar een beetje of een beetje veel worden aangedikt, maakt principieel geen onderscheid; door de bestanade drankwetgeving is de verkoop vası sterkeu drauk nu reeds voor twintig jaar gestignatiseerd. Daaraan is niets te verandereu. Wie een vergunning aauvraagt, weet dit, hij neemt vrijwillig dit stigma an.

En er is meer. Ontegenzeglijk schept de wet een privilegie, dat dus ook door de wet weer kan worden teruggenomen. Alle drankverkoopers weten, dat zij hun bedrijf slechts nitoefeneu bij gu uste - het woord "vergunning" zelf duidt het aan - 
van de gemeeuschap; alle eigenaars van lokaliteiten met vergunning weten, dat zij de meerwaarde van. hun perceelen slechts aan een zoodanige gunst te danken hebben, welke, door de wet geschapen, ook weder door de wet kan worden te uiet gedaan.

Daarom is het eeuig cousequente standpunt, dat dan ook door sommige drankverkoopers wordt ingenomen, te reageeren tegen het begiusel zelf der wret. Maar nu de Regeering dat, ell met goede redenen, niet heeft ingenomen, is het slechts een onlogische aanmatiging om te klagen over hare hardheden eu te verlangen, dat bij hare herziening rekensehap zal worden gehouden met de financieele belangen van de vergunninghouders c. a. Dat doet de Staat niet eens wanneer hij een kanaal graaft of een spoorweg aanlegt, waardoor aan tal van vervoerders huu broodwinning wordt ontnomen; en hoe zou hij het doen teu opzichte van een bedrijf, waaraan hij reeds in 1881 het karakter van een vrije viering heeft ontnomen? Ik acht het van het hoogste gewicht, dat men zich wel doordringe van de warheid, dat wij het stadium yan rekening houden met de particuliere belangen der sterkéudraukverkoopers q. t. in casu al lang voorbij ziju, eu dat dit nu nog slechts tot onzuivere becorrleeling van het aanhangige wetsontwerp en tot gevaarlijke transacties kan leiden. In de Memorie van Toelichting heet het dan ook kort en krachtig van het standpunt van den neringdrijver (bl. 14): "eeu standpunt, dat in deze angelegenheid nimmer dat des wetgevers kan zijn".

Deze dingen zouden voor iedereen duidelijk zijn, wanneer niet, zoonls ik boveu opmerkte, vele bedrijven een samengesteld karakter vertoouden; de verkoop van sterken drank is daarin slechts een element, en vaak slechts een ondergeschikt; wartoe zulke bedrijven ter wille vau een ondergeschikt onderdeel zoo uoodeloos en hatelijk belemmerd? Zeer zeker moet daarin mat gehouden worden, en over die maat laat zich spreken, en ik zal geensains beweres, dat alle door de belanghebbenden aangevoerde bezwaren uit de lucht gegrepen ziju. '). Maar zij ver-

1) Na de uitvoerige, zorgvuldige en haast liefdevolle bespreking, die zij in het V. V. gevonden hebben, kunnen de bezwaarden althans gerust zijn, dat er wèl rekening mede gehouden wordt. 
geteu één ding, n.l. om aan te toonen, hoe het mogelijk zou zijn den verkoop van sterken drank te belemmeren, zonder ook de gecombineerde bedrijven te belemmeren. De strekking van de drankwet, reeds van de oude en nog meer van de nieuwe, is dan vok juist o. m. om die combinaties tegen te gaan. En de houders van zulke gecombineerde bedrijven zijn hard bezig, de noodzakelijkheid daarvan met klemmende argumenten te bewijzen. Want als er iets zonneklaar blijkt uit hun actie tegen het aanhangige wetsontwerp, dan is het dat, wat wij, drankbestrijders, reeds lang wisten en waartegen wij, vooral met een beroep op Engeland, steeds gewarschuwd hebben, te weten : het groote financieele belang, dat de groothandel in wijn en bier heeft bij den kleinhandel in sterken drank. Ook hier geldt precies hetzelfde, wat ik boven zeide: wil men tegen het beginsel zelf der wet ageerell, zoo is dat ten minste logisch, maar doet men dat niet, dan is het even onlogisch als onbillijk van den wetgever te eischen, dat hij zijn beginsel slechts verminkt zal toepassen.

En hier wil ik tot beter verstand der zaak nog een opmerking inlasschen. Men ziet ons, drankbestrijders, er altijd op aan, alsof het grondbeginsel der wet, en de heele wet zelf, dierbaar waren in onze oogen. Reeds een lezing van de verslagen van het vierde anti-alkohol-congres, in 1893 in den Haag gehouden, en waar de Nederlaudsche drankwet aau vrij heftige aanvallen van de zijde der geheelonthouders heeft blootgestaan, kan van dien waau genezen. Draukbestrijding door de wet kan voor ons nooit iets meer zijn dan een episode. Ons eigenlijk werk ligt elders, en waar ous werk is, daar is ook ous hart. Maar is drankwetgeving eenmaal aan de orde, dan kunnen wij natuurlijk er ons niet buiten houden, (dat wordt ons dan ook wel onmogelijk gemarkt!), en als er eenmaal een Regeering is, die flinke maatregeleu tegen het drankmisbruik voorstelt, dan kunnen wij haar natuurlijk niet afvallen; en vooral: als er eenmaal een drankwet is, dan kunnen wij niets anders wenschen, dan dat zij zoo goed mogelijk zij en zoo streng mogelijk gehandhaafd worde.

En hiermede kom ik tot het laatste punt van deze inleiding, men zegt: de drankwet heeft toch al zoo weinig uitgewerkt, wartue haar dau nog verscherpt, waarmede gij ons noodeloos plaagt en het clandestiene drankverbruik slechts doet toenemen? Wij antwoorden: de vooruaamste verscherping, die wij in de 
wet wenschen te rien aaugebracht, is juist haar betere handhaving en krachtiger bestrijding van den clandestienen drankverkoop. Gij erkent, dat de wet slap uitgevoerd is: welnu dan moogt gij er u ook niet tegen verzetten, dat er een proef genomen worde met een betere handhaving, indien gij althans den ernst val uw beweriug, dat ook gij bestrijding van het drankmisbruik wenscht, niet aau gegronden twijfel wilt blootstellen.

\section{De OPPOR'TUNI'THIT.}

Ziju het dus niet de belangen der belanghebbenden die den Staat behoeven en mogen weerhouden om krachtiger tegen het draukgebruik op te treden, het eenige wat hem tot eenige zachtzinnigheid verplicht, dat is zijn eigen houding in het verloopen tijdvak.

Men weet, wat de zaak is. Bij de wet van 1881, art. 2, werd bepaald dat er zouden zijn:

1 vergunning op elke 500 inwoners in gemeenten vau meer dan 50.000 inwoners.

1 vergunning op elke 400 inwoners in gemeenten van $20-30.000$ inwoners.

1 vergunning op elke 300 inwoners in gemeenten van $10-20.000$ inwoners.

1 verguuning op elke 250 inwoners in gemeenten van minder dan 10.000 inwoners.

Diensvolgens hadden er op dat tijdstip in ons land 13.731 vergunningeu mogeu zijn; er waren er echter 33.201. Daarom werd in art. 36 bepaald, dat: $a$. Zij die toen reeds in het bezit van een drankhuis waren, een levenslange vergunning zouden krijgen, terwijl $b$ : Zij, die na 1 Mei 1881 vergunninghouder werden, die "slechts" tot 1 Mei 1901 zóden kunnen behouden. Ofschoon later tengevolge van een uitspraak van den Minister Smidt, die juridisch zich wel verdedigen laat, daaromtrent onzekerheid is outstan, zoo betwijfelt niemand, of de bedoeling van den Wetgever van 1881 is geweest, dat alle na 1 Mei 1881 verleende vergumningen vóór of op 1 Mei 1901 zouden vervallen en het wettelijk maximum op dien datum ten naastenbij bereikt zou zijn. De wegneming van die onduidelijkheid was de eerste en dringendste aanleiding om de herzieuing der drankwet aan de orde te stellen. 
Maar er was nog iets. Zoo weinig heeft de natie in die twintig jaar zich ingericht op den door de wet bedoelden toestand, zoo wouderlijk is de staat door middel van zijn aangewezen organen bij het verleenen van vergunningen te werk gegaan, dat bet teveel thans nog ruim 7000 bedraagt.

Daarbij komen nog de buitengewone vergunningen. Van de gelegenheid daartoe, destijds bij amendement in de wet gebracht, is door Gedeputeerde Staten zoo vrijgevig gebruik gemaakt, dat er tot 1 Juni 19021035 waren vitgereikt, en zulks terwijl men wist, dat het aantal gewone vergunniugen het wettelijk maximum nog altijd zoo enorm overschreed.

Deze nalatigheid van staat en natie maakt het thans onmogelijk de bedoeling van den wetgever van 1881 eenvoudig met geweld tot een feit te maken. Dit zou billijkerwijze alleen mogelijk zijn door uitkoop van die 7000 vergunningen, maar daar zouden, naar de Regeering berekent, een 14 millioen mede gemoeid zijn.

Van den verkeerden kan men dus slechts langs lijnen van geleidelijkheid weder op den goeden weg terugkomen.

Het vorige ministerie heeft nog vóór het verstrijken vau den fatalen termijn een ontwerp ingediend, en wanneer dit terstond op algemeene instemming had mogen bogen, dan had men nog juist er mede gereed kuunen komen. Maar de kwestie van de overtollige vergunningen was in het ontwerp-Borgesius op zoo 'zonderlinge wijze geregeld, dat niemand er vrede mede had. Ter elfder ure werd daarom in der haast een noodwetje aangenomen, waarbij de fatale termijn tot 1 Mei 1904, verschoven werd. De herziening van de drank wet behoorde dus tot de politieke nalatenschap vau het vorige Kabinet aan het tegenwoordige.

Was derhalve het aan de orde stellen van de herziening van de drankwet eeivoudig een noodzakelijkheid, de vraag rijst, of men niet had kunnen volstaan, met de regeling van de evengemelde' anugelegenheid. Maar het spreekt wel van zelf, dat in die 20 jarr allerlei gebreken en leemten in de wet aan het licht waren gekomen, en men mocht dus de gelegenheid niet ver\%uimen, die weg te nemen. Doch moest men niet nog een stapje verder gaan? Moest men de wet niet alleen verduidelijken eu verbeteren, maar ook verscherpen?

Hebben wij zooeven juist geredeneerd, dan is die vraag identisch met deze: heeft het volksbewustzijn omtrent de houding, 
die een beschaafde natie tegenover het drankeuvel past, in-die twintig jaren in Nederland ook vorderingen gemaakt? Is die natie, die destijds de eerste drankwet nauwelijks, of blijkens de ondervinding eigenlijk nog niet, kon dragen, thans reeds in stinat een verscherpte drankwet te verdragen? En wenscht zij dit ook? Anders gezegd: past deze lex reeds bij onze mores?

Het antwoord op die vraag kan m. i. niet twijfelachtig zijn, maar alvorens haar te bespreken, rij nogmaals op haar bijzonder gewicht gewezen, vooral in dit tijdsgewricht. Wij hebben thans een ministerie, dat het hoog houden en verhoogen van het zedelijk peil der natie ook door wettelijke maatregelen in zijn valaudel heeft geschreven. En dat ministerie beschikt over een volgzame meerderheid. Het is dus zeer goed denkbaar, dat deze zulk een wet van dit haar ministerie, die de onderteekening draagt van deu calvinistischen premier en van een katholiek minister, niet zal durvelı afwijzen, en dan ware met de aanneming vau de wet nog' geenszins bewezen, dat zij werkelijk reeds aan den geest der natie bęantwoordt; en dan - men bedenke het wel - dan kon de tweed proefneming wel eens even onbevredigend nitvallen als de eerste.

Of nu de wet aan dien eisch voldoet kan uit al die adressen pro et coutra waarlijk niet afgeleid worden. Maar wel uit de geschiedenis der laatste jaren. En hier komen wij op een terrein, waarop ik eenigszins kan meespreken.

Opgevoed in strenge "matigheid", die geheel met mijn persoonlijken aanleg strookte, in een gezin, waar de Nestor onzer Nederlandsche geheelonthouders, die jaren lang bijna alleen stond ell al de smaadheid ervan gedragen heeft, de onvergetelijke C. S. Adama van Scheltema, onder de huisvrienden gerekend werd, was er nochthans, toen ik in 1882 mijn intrede deed in het openbare leven, geen haar op mịn hoofd dat er aan dacht, dat ik ooit zelf tot de geheelonthouders zou kunnen gaan behooren. En toen ik in 1888 tot dat kuddeke toetrad, was dat nog een heele gebeurtenis, die in de kringen, warin i $k$ verkeerde niet weinig verbazing, om niet te zeggen ontsteltenis, verwekte, en mij terstond in de plants mijner inwoning een zekere, niet bepaald aangeuame, ruchtbaarheid verschafte. Ons aantal was destijds nog zoo klein, dat wij spoedig met elkander bekend werden, en dat uitnoodigingen om als spreker op te 
treden of lid van een bestuur te worden, niet konden uitblijvent. Weinige jaren later was dit geheel veranderd. Toen ik, het was de tweede maal, dat ik in het openbaar optrad, de voorspelling waagde, dat de oude, eerbiedwaardige "Nederlandsche Vereeniging tot afschaffing van den sterken drank" haar werk had gedaan en òf zou verdwijnen òf zich in een geheelonthoudersvereeniging zou omzetten, wekte dat niet weinig de verontwaardiging van een paar veteranen dier vereeniging, die zich onder mijn gehoor bevonden. Luttele jaren later was de profetie vervuld, en niet lang daarna moest zelfs de naam der Vereeniging dienovereenkomstig gewijzigd worden. Bijna gelijktijdig ontstond een machtige beweging in de onderwijswereld, die, schoon ook zij met horten en stooten vooruitgaat, nog geenszins tot staan is gekomen; het aantal geheelonthouders onder de onderwijzers en onderwijzeressen is thans legio, die bijna allen lid zijn van de -Nederlandsche Onderwijzers Propaganda-club, die zich tot ver .over onze grenzen een goeden naam heeft verworven. De samenhang tusschen armoede en drankmisbruik, en mitsdien tusschen socialen arbeid en drankbestrijding werd door steeds meerderen ingezien, en tegenwoordig spreekt het hasst vanzelf, dat wie zich persoonlijk met socialen arbeid afgeeft, geheelonthouder, of voor het minst, een actief afschaffer is. Het kleine kuddeke van vader Scheltema dijde hasst plotseling uit tot de groote en wijdvertakte Nationale Christen Geheelonthoudersvereeniging, geflankeerd door den Nationalen Geheelonthouders Vrouwenbond eu den Kinderbond "De Hoop der Toekomst". Geheelonthouders van andere schakeeringen vouden een onderkomen in de Orde der Goede Tempelieren, den Algemeenen Geheelonthoudersbond e. a. Scheeu het eerst, dat de "Gereformeerden" zich, om welke reden dan ook, ter zijde wilden houden, welhaast werd ook hun de. beweging te machtig, en stichtten zij eigen vereenigingen, en teekenend is het, dat het wetsontwerp, dat ons thans bezig houdt, onderteekend is door dezelfde hand, die nog niet zoo vele jaren geleden (naar men zegt, want gelezen heb ik het zelf niet) de woorden nederschreef, dat de echte Calvinist niet bij den chocoladeketel wordt groot gebracht. !) En den Roomsch

1) De kentering schijnt vooral gekomen na persoonlijke kennismalking met de toestanden in Noord-Amerika. Dit is vooral daarom 
Katholieken verging het eveneens. Zijn de twee Schaepmannetjes, niet tot vermeerdering van den roem van hun doopvader, vermaard, zij konden de totstandkoming van katholieke vereenigingen van drankbestrijding als het Kruisverbond en "Siobrietas" niet tegenhouden. Al deze vereenigingen hebben hun organen en zorgen op ruime scháal voor de verspreiding van geschriften; bovendien zijn er nog onafhankelijke tijdschriften, als de reeds genoemde Wegwijzer en Het Werk der liefde, geredigeerd door den nog altijd ijverigen, thans 88 jarigen oudhoogleeraar Valeton, den tijdgenoot en medestander van vader Scheltema. Het aantal in vereenigingen georganiseerde drankbestrijders-geheelonthouders wordt tegenwoordig op \pm 20.000 begroot, ongerekend de duizendem van het Leger des Heils, die allen geheelonthouders zijn. Reeds driemaal hebben zij een "Nationaal Congres voor Geheelonthouding" kunnen houden en met het beste gevolg; een vierde is in voorbereiding. Veel verdienstelijke arbeid werd en wordt verricht door den Volksbond, die wel wegens zijn "matigheids"-standpunt velen geheelonthouders een doorin in het oog is, maar die toch voor velen een oefenschool in actieve drankbestrijding is geworden, en die door oprichting vanı volkshuizen en dergelijken veel er toe bijdraagt om de geledere van de onderdanen van "Koning Alkohol" te doen slinken. De geheelonthouder, nog niet lang geleden een voorwerp van spot,

gedenkwaardig, omdat Amerika's voorsprong op dit gebied aan deze zijde van den Oceaan gewoonlijk smalend in twijfel getrokken wordt, en omdat Amerika het land is van proefnemingen in wettelijke beteugeling van het drankgebruik. In een artikel in De Standaard van Februari 1899 worden eenige treffende feiten medegedeeld en daaraan deze beschouwing vastgeknoopt: ("Het lran niet ontkend worden), dat het maatschappelijk verkeer in Amerika aan dit principieel tegengaan van deze drinkgewoonte ongemeene verheffing dankt. De jongelingschap, met name aan de Universiteiten, dankt er frisscher kleur, edeler bezieling en reiner leven aan. Het breekt de demonische macht, die in Europa in allerlei drinkusantiën op geheele lagen der bevolking drukt. En waar ten onzent Pauperisme en Drankzucht zoo bijna altoos in onheiligen boud leven, mag in het uitbannen van die drinkgewoonte uit de sociale usantiën zeer stellig één der oorzaken worden begroet, waardoor aan het Pauperisme de mogelijkheid van opkomen in zijn breede vertakkingen belet werd". Vergis ik mij niet, dan heeft de.schijijver zich ook elders in denzelfden geeșt nitgelaten. 
hoon, verbazing of medelijden, wordt thans met zekere wel: willcnde belangstelling, ja beleefdheid begroet; de "blauwe knoop" is geen ongewoon onderscheidingsteeken meer. In particuliere gesprekken, zoowel binnenshuis, als die men in de spoorwegcoupé en dergelijke kan opvangen, neemt de drankbestrijding een veel grootere, en wat nog veel meer zegt, een eervolle plaats in, zoodat personen die eenigen tijd van het vaderland afwezig zijn geweest, van den ommekeer versteld staan. Ontzaglijk veel afbreuk doet de sport an het alkoholgebruik: de opkomst van de "kwast" dateert uit hetzelfde tijdvak. De rekeningen van een iurichting: als het Amstelhotel toonen een sterke vermindering van het wijngebruik aan; de ijzeren wijndwang van vroeger is nit verreweg de meeste restaurants verdwenen; wie mineraalwater bestelt bij zijn eten wordt noch vreemd aangezien noch behoeff meer te betalen, ja zelfs wie in het geheel niet drinken wil, wordt tegenwoordig in vele restaurants niet eens meer met vragen lastig gevallen. Zelfs de studentenwereld heeft har, geheelouthoudersvereenigingeu, en een jongmensch, die een vuurvast geheelonthouder is, kan thaus zich zelfs gerustelijk aan deu groentijd wagen; hem zal geen leed. geschieden. En de veranderde toestand der uatie spiegelt zich ten slotte ook daarin af, dat in de laatste jaren zes besliste geheelonthouders tot leden der Volksvertegenwoordiging zijn gekozen. .

Ziedaar altemaal verschijnselen - en misschien mag het verschijuen van een stuk als dit in een blad als De Ecouomist darr ook toe gerekend worden - waarvan wij voor tien, twaalf jaar, nog niet durfden droomen. Inderdaad een zeldzaam groote verandering in een zoo korte spanne tijds.

En nog heb : ik de twee voornaamste verschijnseleu niet genoemd, die juist met het oog op de wetgeving zoo merkwaardig zijn; de houding van het "volk" zelf, en van de geneeskundigeu.

Merkwaardig is rooral de houding der sociaal-democratische partij in Nederland. Ik moet er uitdrukkelijk bijvoegen: "in Nederland", want elders, bijv. in Duitschland, Noord-Frankrijk, Denemarken, is het niet alzoo. Maar aan de. Nederlandsche sociaal-democratie komt de lof toe, dat zij het mannelijke wachtwoord heeft uitgegeven: "arbeiders, wanneer gij wilt optreden om u een juk van de schouders te werpen, werpt dau eerst 
zelf het drankjuk af $/$. De sociaal-democraten en de friesche volkspartij hebben den nederlandschen werkman geleerd om vergaderingen te houden zonder dat de kroegbaas er één cent bij verdient.

Fn in hun spoor zijn de vakvereenigingen getreden en deze zijn voor de bestrijding van den drank van zooveel gewicht geworden, dat het annstaande nationale congres in het teeken der vakvereenigingen zal geplaatst worden. Wie gevoelt niet, van hoeveel gewicht het juist voor den wetgever is, dat het volk zelf aldus zijn wil te kennen geeft om van den drankdwang bevrijd te worden?

En dan de geneeskundigen. Zeker, nog altijd kunneu de drankbestrijders niet onbepaald op hen rekenen; er is bij velen onder hen, en vooral bij de kopstukken, vaak een halfheid, die verwondering wekt; ofschoon de billijkheid gebiedt te erkennen, dat ongetwijfeld de schroom, om tot de geheelonthouders gerekend te worden, door de wetenschappelijk niet te verautwoorden overdrijvingen van vele geheelonthouders verklaard en verontschuldigd wordt. 1) Doch als men de absolute geheelonthouding er slechts buiten laat, hoe is dan in de laatste jaren in bimuenen buitenland de houding der medische wereld tegenover den alkohol veranderd? Wat al fabelen omtrent de vermeende nuttige eigenschappen van den alkohol zijn, niet het minst door hun medewerking, voor goed naar het rijk der verbeelding verwezen! ${ }^{2}$ ). Hoe beslist luiden hunne uitspraken omtrent zijn schadelijkheid, hoe driugend en ernstig hunne waarschuwingen tegen de gevaren, waarmede hij ons bedreigt, met name in onze progenituur! Hoe eenstemmig zijn zij in hun veroordeeling van het alkoholgebruik, in welke gedannte of hoeveelheid ook, door kinderen beneden de 18 jan!! Hoe naw trekken zij de greuzen van het "matig" gebruik! Hoe positief luidt hun vounis

1) Overigens neernt ook onder hen het anntal besliste geheelonthouders voortdurend toe, die in binnen-en buitenland zich reeds tot afzonderlijke vereenigingen vun artsen-geheelonthonders hebben georganiseerd.

2) Zie om slechts onkelen te noemen Prof. Sttokvis op het $4^{e}$ Internationaal Congres te 's Gravenhage 1893, Compte Rendu pg. 75 Prof. Dr. K. Pel Eubiotiek, Haarlem. Dr. Justus Gaule, Der Lebensgenusz ohne Alkohol. Bern. Dr. Aug. Smith, Die Alkoholfrage. 'Tubingen 1895. Prof. Dr. Th. Ziehen, Geestelịke en lichamelijke ziekteverschijnselen bij kinderen tengevolge van alcoholmisbruik. Prof. Dr. J. van Rees, Vriend of Vijand? enz, enz. 
over het dagelijksch gebruik van kleine hoeveelheden, het bitteren en dergelijken! Hoe onbeschroomd geven zij den drank de schuld van die talrijke verschijnselen van zenuwachtigheid, overspanning, en vooral van degeneratie, die elk na- en weldenkend mensch in onzen tijd met zoo ernstige bekommernis vervulleu! Welk boek of boekje over hygiene of volksgezondheid verschijut er nog, warin niet dringend tegen den alkohol, ook tegen kleine hoeveelheden ervan, gewaarschuwd wordt?

Wanneer men nu bedenkt, welk een groote rol de geneeskundigen in onze tegenwoordige samenleving spelen en hoe hun gezag voor duizenden en duizenden dat vas den geestelijke overvleugeld, ja vervangen heeft, ell wanneer - men nagaat, welke beteekenis de wetenschap in het algemeen voor het thans levend geslacht heeft aangenomen, dan begrijpt men lichtelijk van hoeveel gewricht deze frontverandering van de medische wereld voor de drankbestrijding is. Deze is daardoor als het ware in een nieuw stadium, het wetenschappelijke, getreden. Menigmaal heb ik van medici zelf de uitspraak gelezen: "zoodra wij, medici, er volledig ernst mede maken, en het gezag van ons voorbeeld voegen bij dat van ous woord, dan is het uit met het drankmisbruik."

Voor den wetgever is deze weteuschappelijke ruggesteun natuurlijk ook van bet grootste belang. Zoo langzamerhand wordt het duidelijk, wat de eigenlijke plaats is van den alkohol, n.l. ergens in de buurt van opinm, morphine, arsenicum en dergelijke. Zoodra deze overtuiging gemeengoed der natie is geworden is de tijd daar om den alkohol geheel onder staatscontrole te nemen en hem behalve voor industrieele doeleinden te bannen naar de plaats waar hij hoort: de apotheek.

Dat is misschien nog een lauge weg. Man voor wie goed nadenkt, heeft de staat reeds de eerste schrede daarop gezet, en: "ce n'est que le premier pas qui coûte."

Dit is ook het antwoord op de vraag, die uit het boven gezegde noodzakelijk oprijst, nl.: "als de zaak van den alkohol toch reeds zoo hard achteruitgaat, wat heeft de Staat er zich dan nog mede te bemoeien?" Dat is de groote vrag nar de rol en de roeping van den Staat in zake de drankbestrijding. Daaromtrent zijn alle mogelijke schakeeringen vain meeningen 
in omloop, van degenen af die alles; tot hen, die niets van den Staat verwachten. De nuchtere drankbestrijder zal echter altijd van oordeel zijn, dat de Staat "ni cet excès d'honneur ni cette indignité" verdient; dat de strijd tegen den alkohol allereerst is en blijven moet een persoonlijke en een zedelijke, maar dat de natie dieu strijd ook moet zien afgespiegeld in haar wetten; dat de Staat zijn arm moet leenen, gelijk hij op ieder gebied doet, om de zwakken tegen de bepaald onwilligen te beschermen en om toestanden te bedwingen, die hij alleen beheerschen kan; en dat. het alkoholkraantje altijd zal blijven lekken, als niet ten slotte de Staat het dichtdraait. Bovenal echter staan zij vast in de overtuiging, dat, als de Staat er zich eenmaal mede bemoeit, hij er dan ook ernst mede moet maken en niet met zich moet laten spotten.

De Regeereng heeft zich ook op dat standpunt geplaatst luidens den kloeken aanhef der Memorie van Toelichting, die verdient hier afgeschreven te worden. (De aangebrachte spatieeringen zijn van mij).

$\mathrm{Na}$ opgemerkt te hebben, dat de Overheid niet geroepen is om als "censor morum" op te treden (of dit geheel zuiver is in de Calvinistische leer, zulleu we maar niet onderzoeken!) en dat met name bij het Nederlandsche volk ondersteld unag worden "dat de zedelijke ontwikkeliug veeleer winnen zal in degelijkheid, zoo ze werkt met de harr inhaerente motieven" vervolgt de Regeering :

"Dit mag echter niet zóóver worden getrokken, dat de Overheid ook dan onthouding zou hebben toe te passen, als vaststaat, dat het nationale leven op bedenkelijke wijze is a angetast door een kwad, bevorderd door, zoo niet opkomend uit het bestaan vaninrichtingen, welker gedeeltelijke regeling zijzelve in harehand heeft. Dit nu is onmiskenbarr het geval met opzicht tot de schadelijke gevolgen, die op uitgebreide schaal voorkomen uit het misbruik van den sterkeu drank. De vergiftiging va u e eu annzienlijk deel vau ons volk door den alcohol blijkt empirisch op zeer gevaarlijke wijze de misdaad te vermeniguuldigen, degezondheid totsoms in het tweede en derde geslacht an te tasten, nameloozesociale ellende teweeg tebreugenen het nationale leven te doeu zinkeu. En war alzoo eener- 
zijds het ernstig karakter van het ingeslopen en nog steeds voortwoekerend kwaad niet te loochenen valt, staat anderzijds reeds door de bestaande wetgeving vast, dat de Overheid de haar gestelde grenzen wan bevoegdheid in geen geval overschrijdt, zoo zij den verkoop van den sterken drank aan zekere regelen bindt."

En verder:

"In dien geest handelend, neemt de overheid daarom nog geenszins de persoonlijke actie tegen het geconstateeerde kwaad uit handen van de maatschappij. De persoonlijke actie door de prediking, door het godsdienstig onderwijs, door het volksonderwijs in de school, door onthoudings- en matigheidsgenootschappen, door geschriften en openbare vergaderingen of ook door voorkeur bij het vergeven van betrekkingen aan drankvrije personen geschonken, is en blijft de groote zedelijke kracht vertegenwoordigen, waardoor de vergiftiging van ons volk moet gestuit worden. Maar aan deze sociale actie kan de Overheid een hoogst gewenschten steun bieden door harerzijds den verkoop van sterken drank aan zoodanige regelen te onderwerpen, dat de gelegenheden tot het verkrijgen van sterken drank niet, hetzij door overbodig aantal, hetzij door hare inrichting, het zich verslaven aan de bedwelmende en alzoo zedelijk onvrij makende drankgewoonte in de hand werken."

Zoo dringt ons alles tot het besluit: de tijden zijn rijp voor een verscherpte drankwetgeving, de natie kan gencht worden bereid te zijn zich die te laten opleggen met de onvermijdelijk daaraan verbonden beknellingen van de particuliere vrijheid, en zonder noodeloos ontzien van de daarbij betrokkeu "particuliere belangeu"; bereid ook om tot hare richtige uitvoering meer dan tot dusver hare medewerking te verleenen.

In dit licht gezien kan wat dit wetsontwerp ous biedt zelfs als een minimum worden beschouwd.

Wanneer wij er thans toe overgaan, dit ontwerp meer in bizonderheden te beschouwen, dan zullen wij dit doen in trie rubrieken, die overigens uit den aard der zaak niet streng gescheiden zijn, nl. a. verscherping van het systeem der wet, beoogende beperking van de gelegenheden tot drankverkoop; i. maatregelen om de verleiding tot draukverkoop te vermindereu; 
c. maatregelen tot betere handhaving der wet en tot bestrijdîng van den clandestienen handel in gedistilleerd.

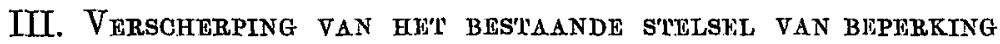 DFR DRANKGELHGHNHEDEN.}

Van dit gezichtspunt uit moet de wetsvoordracht in de allereerste plaats beoordeeld worden. "Ofschoon de wetgever van 1881", zegt de Regeeríng, "zich misschien te eenzijdig op het standpunt heeft geplaatst van de kracht der bestrijding te zoeken in de beperking van het antal drankgelegenheden", toch acht zij het, ook met het oog op den korten termijn, die op 1 Mei 1904 gesteld is, wenschelijk "voorshands nog de proef te nemen, in hoeverre een eenigszins bednidende verscherping van het vigeerende stelsel ten slotte in staat zal blijken, eene geleidelijke verbetering in den toestand te brengeu."

Wij hebben dus thans na te gaau, waarin die verscherping bestaat en of zij voldoende kan geacht worden. Begiunen wij met de kwestie der overtollige vergunuingen.

In het ontwerp Kuyper-Loeff wordt voorgesteld daarop het uitstervingssysteem toe te passen, en wel zonder onderscheid te maken tusschen de vergunninghouders van Art $26 a$ eu die van 26h. Dit is ongetwijfeld de geleidelijke, ja cle zeer geleidelijke weg. Marr het is tevens de meest natuurlijke, en terecht zegt de Regeering, dat op deze wijze de geringste impopulariteit der wet en de meeste medewerking van het publiek te wachten is. Wij achten dit dan ook een verstandig voorstel en leggen er ons gaarne bij neder. ") Maar daarmede moest het o. i. dan ook uit zijn. De Regeering heeft echter uit overmant van zachtmoedigheid nog een douceurtje in voorraad voor de weduwen van hen, die vóór 1 Mei 1909 sterven; deze weduwen zullen ul. het vergunningsrecht tot uiterlijk 1 Mei 1910 mogen behouden. ${ }^{2}$ )

1) Natururlijk is de opheffing van de mogelijkheid van overdracht eever vergunning in $1 \mathrm{Mei} 1904$ daaraan inhaerent.. Dat de "belanghebbenden" dien samenhang niet zien of niet willen zien, kan natuurlijk op den wetgever geen invloed hebben.

2) In overeenstemming hiermede wordt in art. $5 \mathrm{c}$. aan de weduwe van den houder eener vergunning binnen de grenzen van het maximum de voortzetting der vergunning gewaarborgd, mits zij dit uiterlijk 14 dagen vódr afloop van het vergunningsjaar indient. Onze navolgende kritiek geldt m. m. ook deze categorie. 
Dit is inderdaad een curiosum. Hoe komt dezelfde Regeering, die wij zich - zoo kras hoorden uitlaten over het bedrijf der tappers, zoo weekhartig voor hunne weduwen, die hetzelfde bedrijf uitoefenen? Waren hier theologische reminiscenties werkzaam? Het lijkt ten minste een beetje op het "annus gratiae" van predikantsweduwen. Of was het om het verwijt van antifeminisme te ontgan? Andere weduwen, ook van de verdienstelijkste stäatsambtenren, krijgen slechts het loopende kwartaal uitbetaald. Waarmede hebben dan de vergunninghouders deze staatspensionneering hunner weduwen verdiend? Maar als aan hunne weduwen in onderscheiding van alle andere eenige schadvergoeding toekomt voor het verlies van hun echtgenoot, waarom dan slechts aan haar, die v6́r 1 Mei 1909 weduwe worden en niet aan allen? En wat zou lichter te dragen zijn, het verlies der vergunning bij deu dood vau den man, als men toch alles anders moet inrichten en er warschijnlijk geërfd wordt, of eenige jaren later, als de weduwe zichzelf in de nering heeft gezet? Ja maar, zeggen ze, "het standje is een deel van de erfenis, die ik mijn weduwe nalaat" (en ook mijn kinderen, weshalve volkomen consequent velen ook voor hen hetzelfde voorrecht komen annvragen). Ik loochen dit pertinent; ik heb boven reeds aangetoond, dat door de drankwet ann de vergunningen het karakter van een gewone vrije nering is ontnomen. De bepaling, dat de vergunning vervalt bij den dood van den houder is zoo billijk mogelijk en moest eigenlijk van zelf spreken. Voor zijn weduwe moet de vergunninghouder zelf bij zijn leven zorgen door een levensverzekering af te sluiten.

Door de georganiseerde drankbestrijders is tegen deze weduweubevoorrechting nog niet geprotesteerd. Wij hebben echter bij de drankwet al zooveel leergeld moeten betalen voor misplaatste zoetsappigheid, dat ik meen ernstig tegen deze bepaling te moeten waarschuwen. Men kan toch met hasst wiskunstige zekerheid voorspellen, dat het met die weduwen-vergunninghoudsters in 1910 precies zoo zal gaan als met de overtollige vergunninghouders in 1901 .

In tweeërlei opzicht heeft de Regeering de gelegenheid om een zeer voor de hand liggende en gewenschte verscherping anu te brengen verzuimd: In de eerste plaats door het wettelijk 
maximum te laten zooals het is. Met het oog op den verauderden internen toestand clegr watie, die boven geschetst is, en die ongetwijfeld zich nog verder ontwikkelen zal, was er alle aanleiding om dat maximum te verlagen, te meer $\mathrm{nu}$ er door het uitstervingsstelsel . voor een geleidelijke en haast onmerkbare afneming gezorgd is.

Zoowel het uitroerend Drankwet-Comité als de VolksbondCommissie stellen voor het wettelijk maximum door verhooging van het aantal voor één vergunning vereischte inwoners met ongeveer een vierde te verlagen.

Een ietsje heeft de Regeering toch wel gedaan. Zij stelt voor het recht der kroon om op voorstel van den gemeenteraad het maximum te verhoogen, warvan trouwens nooit gebruik is gemaakt, te doen vervallen, en het correspondeerende recht om het maximum te verlagen, uit te breiden tot het maximum $\mathrm{n}$ ul. Bij gebrek aan nadere bepalingen zal deze verlaging tot nul c.q. alleen tot stand kunnen komen door uitsterving van alle platselijke vergunninghouders. Ook is er een onduidelijkheid overgebleven. Als in een gemeente het maximum is verlaagd, kan dit maximum dan niet weder $v$ e r h o og $d$ worden ? of kan het ten allen tijde weder op het wettelijk maximum worden teruggebracht?

In plaáts van verlaging heeft de Regeering feitelijk een verhooging der maxima voorgesteld door 't bepaalde in artt. 3 eu 5 van het ontwerp. Er zullen $\mathrm{nl}$. in het vervolg niet meer alleen verguuuingen worden uitgereikt door Burgemeester en Wethouders, maar ook rechtstreeks door Gedeputeerde Staten. Deze vergunningen zullen worden uitgereikt 1 : aan logementen voor den drankverkoop alleen aan logeer- en vaste tafelgasten '), welke verkoop tot nog toe geheel vrij was (art. 15 der bestaande wet ${ }^{2}$ )) en aan Societeiten ten opzichte ran hun leden. D e z e vergunningen nu zullen niet mede tellen bij de berekening van de maxima, die daarmede dus feitelijk

1) Deze vaste tafelgasten zijn een - trouwens onafwijsbare toevoeging.

2) Daarentegen blijft de wet nà als vóór niet toepasselijk op drankverkoopers aan militairen in dienst. De "drankverkoop aan boord van vaartuigen aan de opvarenden" wordt vervangen door : "de drankverkoop op of in openbare middelen van vervoer uitsluitend voor reizigers." Dat is waarlijk ook geen verbetering; was misschien voor internationale treinen en stoombooten een uitzondering niet te vermijden, waarom die dan niet met de logementen gelijkgesteld? 
zulleu worden verhoogd, en- wel in een mate, waarvan het eind niet te overzien is. Het is inderdaad onbegrijpelijk, hoe een Regeering, die zoo duidelijk toont dat het haar ernst is met de wettelijke beteugeling van het drankmisbruik, een zoo destrueerende bepaling in-haar ontwerp heeft kunnen opnemen. In de Memorie van Toelichting ontbreekt elk woord van verklaring. Het is al erg genoeg, dat er voor de logementen een uitzondering moet worden-gemakt, en het is als een kleine verbetering aan te merken, dat deze nu ten minste ook een vergunning zullen noodig hebben; maar reeds hier is de ontduiking maar al te gemakkelijk; wie heeft nooit bijgewoond, dat een logementhouder een bezoeker een glas "ten geschenke" aanbood? En hoeveel lichter zal dat vallen bij de "Societeiten"! Hier is het proefondervindelijk bewezeu, dat zij gemakkelijk gefingeerd worden. De voorgestelde waarborgen - bij de aanvrage zal een afschrift of afdruk van statuten en reglementen moeten worden overgelegd, en Gedeputeerde Staten $\mathrm{k}$ unnen opgave vorderen van de leden - zijn ten eenenmale onvoldoende te achten. Wie controleert die lijst? In Art. $\mathrm{X}=$ art. $3^{\circ}$. nieuw wordt gezegd, dat de verguuning zal worden geweigerd, wanneer de Societeit niet te goeder trouw Societeit is: wie makt dit uit? ') En hoe moet het gaan met de geintroduceerden? En ook zonder eenige fraude: hoe gemakkelijk zal het niet zijn vour allerlei kringen en kringetjes om hun "Stammkneipe" of het bierhuis, waar zij tot nog toe clandestienen drank genoten, in een societeitje te herscheppen? Zoo wordt, ten eenenmale in strijd met het hoofdbeginsel der wet, het aantal drankgelegenheden tot in het onafzienbare vermeerderd; of, zoo dit niet geschiedt, het zal niet de schuld zijn der. wet; want wat zullen de overheden er aan kunnen doen, ook met den besten wil der wereld? En met alle eerbied voor de overheid en het tegenwoordig zoo hoog genoteerde "gezag" mag men in deze toch als rechtschapen ell ordelievend burger wel vragen, met het oog op de uitvoering rer bestaande drankwet, of die goede wil altijd in voldoende mate bij de overheden aanwezig zal zijn? Wij zijn aan zulke wonderlinge uitvoeringen en opvattingen van de drankwet gewend geworden! Wat de Regeering hier doet, dat is feitelijk

1) Op die "goede trouw" wordt door de Regeering nog al eens meer een wissel getrokken. 
een nieuwe categorie van buitengewone vergunningen scheppen, en dat terwijl zij de oude handhaaft (waarover straks) : hebben wij daarvoor nog niet leergeld genoeg betaald?

Fn dat alles is nog het ergste niet; het ergste is, dat hierdoor de hoogere standen weder ontheven worden van hun dure verplichting om, ook door het dulden van eenig persoonlijk ongerief, aan de verlossing des volks van de tyrannie van den drankduivel mede te werken.

De zedelijke grondslag van de drankwet zelf komt hier in gevaar. Vroeger mocht men dit nog niet zoo inzien, thans weet men beter. De strijd tegen den drank moet, minstens voorzoover hij door wettelijke maatregelen gevoerd wordt, een n a ti o u a le zijn. Hij moet dus door alle standen gelijkelijk gevoerd, de lasten ervan mogen niet op enkele lagen der bevolking alleen gelegd worden. Zoo ergens, dan is hier sprake van "solidariteit". Erenmin als er mogelijkheid bestaat om een flinken strijd tegen den alkohol te voeren als men al de belangen van de drankverkoopers wil ontzien, evenmin is dit mogelijk zonder den "fatsoenlijken" societeitsbezoeker nu en dan te doen gevoelen, dat er een wet tot beperking van den drankverkoop in het klein bestaat. Iets ondemocratischer kan ook moeilijk bedacht worden, dan "het volk" onder staatsvoogdij te zetten en tegelijkertijd de "heeren" in hun openlijke drinkgewoonten volkomen vrij te laten. En zulks te minder, waar hun drinkgewoonten waarlijk niet minder aan den grooten weg timmeren dan die van den handwerksman. Integendeel, als de kroegen gesloten wordeu, dan stroomt de lichtzee uog uit de weelderige societeitsgebouwen over onze, marktpleinen heen. Meent men soms, dat dit geschikt is om de wet "minder impopulair" te maken?

Dit alles klemt te meer, omdat societeiten en logementen een aantal voorrechten zullen genieten die de Regeering zelf (Memorie van Toelichting blz. 8) opsomt: zij zullen niet uit zekere buurten kunnen geweerd worden, de vergunningen van deze inrichtingen zullen ook an andere dan natuurlijke personen kunnen verleend worden en aan logementen zelfs kosteloos; voorts zijn zij vrijgesteld van allerlei eischen en straks nog te bespreken bepalingen, die ten doel hebben in de drankgelegenheden althans een zekeren standaard van moraliteit op te houden.

En waarvoor is het noodig? De bestaande Societeiten 
loopeu gee山 gevaar. Eu de toekomstigen? Waarom moeten toch al die dingen een vergunuing hebben? Als de "fatsoenlijke" menschen zich uòg geen plaats van samenkomst kunnen denken zonder alkoholgebruik, dan wordt het toch waarlijk tijd dat zij zich vau hun achterlijkheid genezen "); in ieder geval behoeft de staat met die achterlijkheid geen rekening te houden. Ik durf wel zeggen, dat het opkomende geslacht dit privilegie niet eens verlangt ${ }^{2}$ ). In Jena, anders waarlijk geen geheelonthouders-clorado, heb ik genoten van een heerlijk leesmuseum; men vond er alles, van het kleinste volksblad af tot het meest wetenschappelijke tijdschrift toe, gevolg van de combinatie van eeц wetenschappelijk leesgezelschap met een volksleeszaal; toegaug en uitleening der boeken was geheel kosteloos; het was er altijd gezellig vol; manr er was absoluut niets te krijgen, dan eeu glas water; er werd niet gedronken, niet gesproken en - o zaligheid niet af te meten, en in Holland, anders dan op een damesleesmuseum ondenkbar - niet gerookt!!

De "heeren" hebben bovendien altijd nog den uitweg van het huren van een zaal in een vergunninghebbend café.

En wat ten slotte alles afdoet: het is een stap achteruit, want tegenwoordig tellen de societeiten wèl mede onder de gewone vergunningen. En stappen achteruit te doen, dat is de bedoeling van de arnhangige herziening niet.

Deze bedenkingen moeten daarom nog zooveel zwaarder wegen, omdat de Regeering, zooals wij reeds arnduidden, de beruchte "veiligheidsklep", de buitengewone vergunningen van art. $2,3^{\circ}$, wil behourlen. Hoe gul daarmede is omgesprongen ${ }^{3}$ ),

1) Niemand beter dan de Regeering zelve zou het hun kunnen leeren, die in de M. v. T. zoo schoon schrijft : "De maatschappelijke opvatting in zake den sterken drank is thans een geheel andere dan in 1881. Kon men toen nog zeggen dat gelegenheden voor maatschappelijk verkeer niet mogelijk waren, zonder dat sterke drank kon worden verstrekt, thans heerschen andere denkbeelden; niet langer zijn gelegenheden voor maatschappelijk verkeer in zoo volstrekten zin als vroeger afhankelijk van don alkohol; in steeds ruimer wordende kringen beschouwt men dezen veeleer als zeer wel misbaar of zelfs als schadelijk en wordt hij, , zooal nog geduld, toch niet zelden geweerd."

2) Verg. de vorige noot.

3) Verg. de interessante studie van Mr. H. P. Berdenis van Berlekom, Vragen des Tijds. 1890. II. 
blijkt wel uit het feit, dat, zooals de Memorie van Toelichting. ous mededeelt, er op 1 Juui 1902 reeds 1035 van die buitengewone vergunningeu bestonden; en dat, niettegenstaande de twintigjarige overgangstijd reeds verstreken en het aantal wettige vergunningen, nog altijd zoo veel te groot was, er in de laatste twee jaar nog 329 nieuwe verleend ziju. Eén verbetering wordt voorgesteld, die dankbaar moet worden aanvaard: het recht van uitreiking wordt Gedeputeerden Staten, die dan ook hun onbevoegdheid daartoe rijkelijk bewezen hebben, ontnomen en overgebracht aan de Kroon. Van deze verbetering wordt echter in de Memorie van Toelichting wel wat veel ophef gemaakt; ook schijnt de Regeering een "zzeer" belangrijke beperking hierin te zien, dat buitengewone vergunningen in het vervolg alleen zullen kunnen worden verleend aan "buitengewone inrichtingen vau maatschappelijk verkeer", een uitdrukking, die sterk uitlokt tot satirieke randbemerkingen en zonderling strijdt met de boven (pg. 132, noot 1) aangehaalde woorden uit $\S 5$.

Wij zien dau ook niet in, wat de Regeering heeft kunnen weerhouden, om deze ongelukkige bepaling thans geheel uit de wet te lichten.

Op deze bejde punten, het brengen vau de Societeiten onder de gewone vergunningen en het opheffen van de "buitengewone", heerscht wederom een verblijdende overeenstemming tusschen de Volksbond-Commissie en het Uitvoerend Drankwet-Comité.

Nog op een ander zeer gewichtig punt is de Regeering o. i, in gebreke gebleven, de wet "up to date" bij te werken: ik bedoel de bierhuizen. Wel trekt het ontwerp thans ook deze binnen de sfeer van de bemoeiingen der overheid, maar alleen uit het ougpunt val bestrijding van den clandestienen drankverkoop, waarover straks zal te spreken zijn.

Marr beperking van het antal bierhuizen wordt noch voor nu noch voor de toekomst voorgesteld.

En toch was daar alle reden toe.

Dank zij alweder den vorderingen der wetenschap. weten wij thaus genoegzanm wat wij van de beweerde onschadelijkheid el de nuttige eigeuschappen van het bier hebben te denken; de weteuschap komt daarmede wel wat laat tot een inzicht, waarvan reeds de vader van het teetotalisme, de eenvoudige John Livesey 
voor ruim 60 jaren is uitgegaan '); maar enfin, zij kumt er danı toch, en onwetendheid kan thans niemand meer voorwenden. $W_{\text {ij }}$ weten thans te góed, dat alkohol alkohol blijft, onverschillig of hij in wijn, bier of gedistilleerd voorkomt; en al wordt ook door ous geenszins ontkend of miskend (zie h. o. bl. 137), dat de concentratiegraad, en de vermenging met zekere essentiën njet zonder invloed zijn op zijn nitwerking, hij blijft eeu vergif, welks specifieke eigenschap het is, in de normale functie van een of meer deelen van het organisme tijdelijke of blijvende storingen teweeg te brengen. ${ }^{2}$ ) De verslagen van herstellingsoorden voor drankzuchtigen, als bijv. het bekeude Ellikon, spreken van een 30 pCt. slachtoffers van wijn-, bier- of cidergebruik. Bekend ziju de opzienbarende. onderzoekingen van Prof. Bollinger te München over de Münchener "bierharten". Ik heb vroeger eens een opzettelijk onderzoek ingesteld naar de waarheid der bewering, die nog dierbaar is aan veler harten, en ook in de Memorie van Toelichting weer opduikt, dat men met den bier-Beëlzebub den drankduivel kon nitdrijven. Ik heb toen gevondeu, dat inderdaad in Engeland in de XVIII eeuw al naar mate meu den accijns verplaatste, het bierverbruik toe- en het drankgebruik afnam en v.v., maar dat minsteus sints het midden der $\mathrm{XIX}^{\mathrm{e}}$ eeuw beiden tegelijk tegen alle verdrukking in groeien zoodat in wiju- eu bierdrinkende lajnden het gebruik van gedistilleerd, in brandewijn- of jeneverdrinkende landen dat van bier groote vorderingen maakt. ${ }^{3}$ ) Ik meen te weten, dat dit

1) Zie John Levisey's Woord over de Moutdranken, vertaald en toegelicht door J. F. Beijen, C. H. E. Breyer. Utrecht.

2) Prof. Stolvvis 1. c.: "Je n'hésite pas à considérer l'alcool, dans toutes ses formes et dans toutes les conditions, (ik spatieer) coinme une substance, qui entrave nos facultés intellectuelles." (Dit verslag is door Prot S. zelf aldus schriftelijk geformuleerd. In 't mondeling debat op 't Congres zelf waren zijn uitdrukkingen nog krasser.) $\nabla$ gl. Prof. J. W. Gunning, Moet de alkohol ook in zuivver wetenschappelijken zin een vergif genoemd worden? in "De Wegwijzer," Jrg. II bl. 277.

3) Zie: Een sociale lkwestie in "Bouwsteeneu. Tijdschr. v. inw. Zending". 1897. Het opvallendst is in dit opzicht de lijdensgeschiedenis van Frankrijk. Zie het allerbelangrijkst artikel van Jules Denis, Recherches sur la consommation des boissons distillées et fermentées dans différents pays. Bericht des. V. intern. Kongress za Basel 1895. pg. 173-220, (bijna uitsluitend tabellen en statistieken). 
door latere statistieken ten ,volle wordt bevestigd. De medische wetenschap stemt daarmede in bij-monde van den beroemden voll Pettenkofer, die in 1895 zeide: "ide een tijdlang gekoesterde verwachting, dat het toeuemend bierverbruik een merkbare afneming van het verbruik der versçhillende sterke dranken zou brèngeu, is niet vervuld geworden:" En hij voegde er bij: "Het geringe alkoholgehalte van het bier wordt rijkelijk te niet gedaan door de groote hoeveelheid, waarin het gedronken wordt." En Prof. Aug. von Strümpell zegt '): "Geen denkbeeld is nit medisch oogpunt valscher dan te meenen, dat de verdringing van andere alkoholische dranken door het bier den verderfelijken invloed van den alkohol zou doen verminderen." Ontrent de dwaze en reclameachtige beweringen, dat bier waarde heeft als voedingsmiddel zij het voldoende te verwijzen nar de uitnemende studie van dr. S. Birnie, Voedende bestanddeelen van bier. ${ }^{2}$ )

Men ziet, dat het bier al hard op weg is het gedistilleerd te volgen op den weg, waar dit zijn reputatie als onschadelijk geuot- en nuttig versterkingsmiddel zoo jammerlijk verloren heeft.

En de sociale en paedagogische gevaren van het bier zijn vooral niet minder. De jeugd begint bijna nooit en nergens met gedistilleerd; de weg tot den drank voert voor haar bijna altijd en overal door den wijn en het bier; het bierhuis is het voorportaal van de kroeg, en de eerste oefenschool van tal van sociale ondeugden.

Wordt deze gelegenheid om het biergebruik te breidelen, niet aangegrepen, dan is het niet te zeggen, welke toestanden ons nog te wachten staan. Reeds nu wordt in Limburg tot de uitrusting van een huishouden gerekend te behooren een tapkast voor den bierverkoop!. In Maastricht is één bierhuis op elke zes woningen en dat is geen uitzonderingstoestand!

Het Kamerlid voor Weert, de heer Jan Truijen, gaf bij de vorige drankwetsherziening het volgende overzicht van het aantal drank- en bierhuizen in dat district:

1) „Ueber die Alkoholfrage vom aertzlichen Standpunkt aus. Vogel. Leipzig.

$\left.{ }^{2}\right)$. Wegwijzer Jrg. I. 


\begin{tabular}{|c|c|c|c|c|c|}
\hline Gemeenten. & $\begin{array}{l}\text { Bevolking } \\
\text { naąr de' } \\
\text { volks- } \\
\text { telling. }\end{array}$ & $\begin{array}{l}\text { Aantal } \\
\text { drank- } \\
\text { huizen. } \\
\text { in } 1881 .\end{array}$ & $\begin{array}{l}\text { Aantal dranl } \\
\text { met ver- } \\
\text { gunning. }\end{array}$ & $\begin{array}{l}\text { huizen in } 1900 \\
\text { met en } \\
\text { zonder ver- } \\
\text { gunning. }\end{array}$ & $\begin{array}{l}\text { Aantal } \\
\text { inwoner: } \\
\text { voor éér } \\
\text { drankhuis }\end{array}$ \\
\hline Buggenium & 663 & 10 & 3 & 15 & 414 \\
\hline Grathem & 1086 & 26 & 3 & 42 & 26 \\
\hline Haeleu & 818 & 26 & 3 & 31 & 26 \\
\hline Heythuyzen & 2173 & 83 & 3 & 35 & 62 \\
\hline Helden & 4259 & $\left.70^{1}\right)$ & 15 & 98 & 43 \\
\hline Horst & 4569 & 70 & 19 & 87 & 53 \\
\hline Hunsel & 999 & 11 & 4 & 32 & 32 \\
\hline Kessel & 1387 & 32 & 6 & 53 & 26 \\
\hline Maasbree & 6772 & 130 & 28 & 183 & 37 \\
\hline Meijel & 1649 & 33 & 8 & 419 & 34 \\
\hline Nederweert & 5134 & 85 & 19 & 115 & 40 \\
\hline Neer & 1606 & 26 & 3 & 31 & $5 \dot{2}$ \\
\hline Neeritter & 649 & 22 & 1 & 23 & 28 \\
\hline Nunhem & 261 & 8 & 1 & 11 & 24 \\
\hline Roggel & 1701 & 22 & 3 & 33 & 52 \\
\hline Sevenum & 2111 & 22 & 7 & 38 & 56 \\
\hline Stramproy & 1211 & 15 & 4 & 28 & 43 \\
\hline Weert & 8677 & 91 & 41 & 233 & 37 \\
\hline Totaal & 45725 & 722 & 171 & 1137 & 40 \\
\hline
\end{tabular}

De vraag naar beperking van den bierhandel is algemeen: zal die vrang van het volk door de Volksverte ge en w o ord ig ing beantwoord worden met een flinke, afdoende regeling dezer materie?

Het "Uitwoerend Drankwet Comite" vraagt de uitbreiding van het aantal bierhuizen tegen te gaan, door ook hiervoor maxima uit te stellen in verhouding tot het aantal inwoners eener plaats. Een bescheiden stap in die richting, meent het Comité, zou rijn het thans bestaande aantal bierhuizen als maximum an te nemell, met dien verstande, dat waar dit aantal meer is dan: 1 voor elke 100 . inwoners op plaatsen beneden 20.000 zielen 1 " " 150 " " " 50.000 " ell 1 1" " 200 " grootere plaatsen, dit door "uitsterving" binnen dat aantal zal worden teruggebracht.

De katholieke St. Paulusvereeniging, die werkt te midden dẹr biertoestanden val Brabant, vraagt eveneens beperking van het aantal, 'en de Volksbond-Commissie wenscht, dat de uitbreiding zal worden tegengegaan of bemoeilijkt.

1) Dit is een schatting. 
Teleurgesteld gevoelen de drankbestrijders zich ook hierdoor dat de Regeering de opbrengst van het vergunningsrecht aan de gemeente laat in plaats van dit in de Rijkskas te laten vloeien, desnoods met billijke vergoeding aan de gemeenten.

Tem slotte nog iets, dat vele drankbestrijders ongaarne in dit ontwerp missen, nl. een verbod van invoering en verkoop vau absinth. Dat het absinth verreweg de gevaarlijkste is van alle alkoholhoudende drauken, daarover zijn alle autoriteiten het eens. De daardoor verwekte storingen onderscheiden zich zelfs door specifieke vormen en bijzonder hevigen graad. $\mathrm{Nu}$ is het absinthgebruik in Nederland op het oogenblik niet inheemsch; een verbod zou niemand hinderen en zou nauwlijks gevoeld worden. Maar men weet nooit wat er geschieden zal, als de mode er zich mee in mengt. Evenals wij eenige jaren geleden door haar een plotselinge overstrooming hebben gekregen met een nietalkoholischen, zeer gezonden drank, den "kwast, " even goed kan een volgende gril van de oude dame ons den ganschen jammer van het fransche absinthgebruik brengen. Waarom dat niet verhoed, nu het zoo gemakkelijk kan? Zegt niet deze zelfde Regeering in haar Memorie van Toelichting elders zoo uitnemend schoon en waar: "Het is voor den Nederlandschen wetgever zaak, zich aan anderer voorbeeld te spiegelen en niet te wachten tot het kwaad verder heeft voortgewoekerd. Gouverner c'est prérvoir." De beide Comités dringen dan ook aan op een verbod vau verkoop en aanmaak van absinth.

Boven is gesproken over een anvulling van Art. 7 met een bepaling, die het mogelijk make het aantal vergunningen in een plaats ook nog op andere wijze dau door uitsterving te doeu dalen. Deze aanvulling wordt verlangd met het oog op iets wat in de wet staat ell op iets wat er niet in stant: de invoering van het Gothenburgerstelsel en viln "Local Option." Over beideu zal ik kort zijn.

Met het Gothenburger stelsel, 1) wararbij een aantal vergun-

1) Zie hierover o. m. G. F. Egidius in de Gids van April 1882, J. Graham Brooks in The Economic Journal van 14.Juni 1894. (door: mij vertaald en met een naschritt voorzien in De Baanbreker, .Trg. I. Slothouwer, Amersfoort 1894.) Th. W. van der Woude: in De Wegwijzer Jrg. IV en VII en het rapport van de Volksbond-commissie 
ningen onder zekere voorwaarden worden afgestaau aan eể maatschappij of remuootschap, wier "lokaliteiten" en zetbazen de kroegen en kroegbazen rervangen, wil de Regeering een proef nemen. Ofschoon erkennende, dat het oubewezen en onbewijsbaar is, dat dit stelsel in de landeu, waar het ingevoerd is, het drankverbruik heeft doen afnemen, acht zij het, bij de bestaande sympathie voor dit stelsel, "raadzaam, aan de krachten ten goede, die in de samenleving schuilen, ten deze den weg tot medewerking te openen."

Die sympathie is vooral te vinden in de kringen van den Volksbond. Bij de echte geheelonthouders staat het Gothenburgerstelsel in een kwaden reuk, omdat het slechts de uitwassen, de onfatsoenlijke en hinderlijke uitingen van het drankgebruik wegneemt, maar juist om dat waas van fatsoeulijkheid, waarmede het de drinkgewoonten bestrijkt, lijkt het hun dubbel gevaarlijk. En ook daarom keuren zij het af, omdat het weder financieele belangen aan den drankhandel vastkoppelt. ') Evenwel erkend moet worden, dat door Mr. A. van Gijn onlangs in dit tijdschrift een verbeterde vorm van dit stelsel is ontworpen, die aan vele bezwaren tegemoet zou komen. De hoofdzak is, dat de overwinst nitslnitend besteed worde voor maatregelen van drankbestrijding, en niet zooals in Gothenburg zelf, in de openbare kas vloeie, of zooals in Noorwegen, aau maatregelen van algemeen nut worde besteed. Door de beide meergenoemde Comités wordt dan ook zoodanige bepaling gevraagd. Hoe de Regeering zich eigenlijk de zaak voorstelt, ligt vrijwel in het duister, daar de geheele nadere regeling wordt overgelaten aan een A. M. V. I. B.

Veel zal er dus van afhangen, hoe die vitvalt. Daar echter iu de wet de bepaling is opgenomen, dat een tapperijmaatschappij met niet meer dan hoogstens vijf vergunningen beginnen en afwachten moet, totdat die vrijkomen, en dat zij niet alle haar

(Mr. F. W. J. G. Snijder van Wissekerke en A. van den Voort Az.) en eindelijk Mr. A. van Gijn, De Drankwet, in dit Tijdschrift 1903, en thans ook een, blijkbaar door of namens den Volksbond uitgegeven, brochure van denzelfde: "Een verbeterd Gothenburgsch stelsel." November 1903.

1) Zouden de ernstige bezwaren daartegen, die de Regeering op bl. 12 der Memorie van Toelichting ontwikkelt, heuseh viet gelden voor de tappersmaatschappijen? 
verleende vergunningen in exploitatie zal kunnen brengen (op zichzelf een aanbevelenswaardige bepaling,) zoo is het te verwachten, dat het met de invoering van het Gothenburgerstelsel in Nederland zoo'n vaart niet loopen zal. Het geheelonthoudershart kan dus gerust zijn.

Is het Gothenburgerstelsel dierbaar aan de drankbestrijders type-Volksbond, de meeste volbloed-geheelonthouders dweepen met Local Option, dat is het toekennen van het recht aan alle meerderjarige inwoners eener gemeente om bij meerderheid vasu (meestal twee derden der) stemmen te beslissen, dat gedurende een zeker aantal jaren alle drankverkoop in de gemeente zal verboden zijn. Ik deel hun meening niet, en ik heb indertijd in De Baanbreker (l. c.) gezegd waarom. Ik zie er in een tweesnijdend zwaard, en geen specitiek middel van drankbestrijding.

Bedoelde geheelonthouders schijnen echter van meening te zijn, dat anls het Gothenburgerstelsel wordt ingevoerd, hun de Local Option toekomt, hetzij dan als een correctief op het eerste, hetzij als een soort van vergoeding. En daar de Regeering in de Memorie van Toelichting vrij duidelijk te kennen geeft, dat als hare (m. i. niet gezochte) constitutioneele bedenkingen worden opgeheven, zij wel tot de invoering vau dit nov um wil medewerken en daar er op 't oogenblik, zoonls de welwillende lezer bemerkt heeft, tusschen de verschillende soorten van drankbestrijders een schoon kartell bestaat en dit kartell opneming van de Local Option naast het Gothenburgerstelsel gevraagd heeft, zoo wil ik deze harmonie en de opgewekte verwachtingen niet storen en bepaal mij tot de opmerking, dat ik mij persoonlijk voor geen van beiden koud of warm zal maken.

Bovendien bevat het ontwerp nog een reeks bepalingen, nauvulling of verduidelijking der bestaande wet beoogende, die op dezelfde lijn liggen van beperking der drankgelegenhedeu, eu waarvan wij de voornaamsten kort willen aanstippen, zonder commentaar, want o. i. zij bevelen zichzelf aan. ')

Lokaliteiten, an openbare machten toebehoorende, zullen geen vergunning meer mogen hebben. Moeten lokalen met vergunning voor den openbaren dienst worden gebruikt, wat soms

1) Dat zij niettemin tot veel kritiek aanleiding kunnen geven, bewijst het V. V. 
onvermijdelijk is, dan mag er gedurende dien tijd niet getrpt worden. Het begrip "localiteiten die roor den openbaren dienst gebruikt worden", waarin niet mag worden geschonken, wordt uitgebreid. Verkoop vau sterken drank op den openbaren weg. wordt uitdrukkelijk verboden. De in 1885 te kwader uur.in de wet gebrachte mogelijkheid om vergunning te verleenen ain niet-physieke personen wordt weer opgeheven. ') Niemand zal meer dan één vergunning kunnen krijgen. De vergunninghonder moet wonen in het huis, waarin de vergunning gevestigd is. ${ }^{2}$ ) De verboden cumulatie van neringeu, tot nu toe beperkt tot "winkelneringen", wordt nitgebreid tot elk "bedrijf" zonder onderscheid, de lijst van beroepen, die niet met dat van vergunninghouder kunnen gecombineerd worden, wordt zeer doelmatig aangevuld met die van scheepsbevrnchter en stevedore. Vergunningen zullen niet verleend worden wanneer de verzoeker of rijn gezin te kwader naam en fam bekend staau, enz. en\%.

IV. Bepaltngen, BeOOGENDe het thgengaAN faN DF VERLIEIDING TO'T DRANKMISBRUIK.

Al het tot dusver besprokene bewoog zich op de liju valt beperking van den kleinhandel in den sterken d rank, die, reeds blijkens haar titel, het eigenlijke doel van de wet is. Maar de Regeering meende terecht, dat zij van deze lijn niet afwijken zou, door ook bepalingen op te nemen omtrent de wijze, warop de drank ten verkoope wordt aangeboden, met het doel om de verleiding te verminderen en een zekere moraliteit in de drankgelegenheden te handhaven. Immers zij deed daarmede, naar zij zelf opmerkt, niets anders dan een kiem, die reeds in de wet aanwezig was, tot ontwikkeling brengen, nl. de bepaling van art. 2 laatste lid sub $2^{\circ}$, die an den gemeenteraad de bevoegdheid geeft eischen voor de dranklocaliteiten vast te stellen, Het zijn wederom gulden woorden, die de Regeering daaromtrent te lezen geeft, en wij kuunen ons

1) De Regeering stelt voor, de bestaande vergunningen aan vennootschappen te laten afloopen in 1935 . De drankbestrijders vinden dien termijn, dien de Regeering voorstelt als een middenweg, wat al te lang.

2) Die bepalingen zijn niteraard niet toepasselijk op de tapperijmaatschappijen, noch op de vergunningen, die door Gedeputeerde Staten verleend worden. 
het genoegen niet ontzeggen, daaruit het voornaamste aan te halen.

"In de eerste plats is een scheiding noodig tusschen verkoop van sterken drank voor verbruik ter plaatse en voor verbruik elders. Vooral in de arbeiderswijken is, wie sterken drank voor gebruik elders dan in tapperijen wil koopen, aangewezen. op tapperijen of op slijterijen met vergunning. Hierin licht ten deele een sterke verleiding voor den kooper, ten deele wordt daardoor aan den verkooper een gelegenheid gegeveu, om tot drinken aan te moedigen. Deze vereeniging van gelegenheden heeft in de arbeidersklasse menigmaal de drinkgewoonten in de hand gewerkt.

"Iu de tweede plaats mag de inrichting van de lokaliteiten, waar sterke drank verkocht wordt, niet langer worden overgelaten an het goedvinden van de tappers. De dranklokalen, die door geheimzinnigheid en door zorgvuldig verborgen te houdien, hetgeen daarin plaats heeft, en daaronder niet zelden velerlei ongerechtigheden, een voor menigeen to sterke aantrekkingskracht hebben, en den bezoeker in een atmosfeer bevangen, warin hij spoedig daalt tot het peil der gewoontedrinkers, die daar samen komen en er geëerd worden, mogen niet langer, ten'schade van zoovelen, onveranderd geduld worden. Ten eerste zullen dus bij algemeenen matregel van bestuur eischen moeten worden gesteld, waaraan de lokaliteiten moeten voldoen, voor welke vergunning verleend mag worden (Art. 2a); ten tweede moet het geheimzinnige, de verberging van wat het daglicht niet zien mag, worden verboden, met name zullen de lokaliteiten gelijkvloers aan de zijde van den openbaren weg moeten zijn (artt. 3,8 en $9^{\circ}$ ), zullen zij van dien weg af inzicht moeten geven (eodem $10^{\circ}$ ) en zal het verboden zijn, het inzicht van den openbaren weg te belemmeren (art. $15 \mathrm{k}$ )."

Er zal dus scheiding worden gemaakt tusschen tapperijen en slijterijen, en wel een absolute. De tegenwoordige bezitters van beide gelegenheden zullen moeten kiezen of deelen. Dit beteekent dus feitelijk een vrij krasse vermindering van het aantal vergunningen tot tappen. Het bedrijf van slijter zal bovendien onvereenigbaar zijn met dat van verkooper van eenigen anderen drank. In tapperijen mag niet bij de maat worden verkocht noch ten gebruike elders, en in slijterijen slechts ten verkoop elders en niet anders dan in goed gecapsuleerde flesschen 
van minstens $\frac{1}{2}$ liter inhoud. Altemaal voortreffelijke bepalingen.

Dat geldt in niet mindere mate van de aan de lokaliteiten te stellen eischen, waardoor alle geheimzinnigheid, alle verstoppen, onmogelijk wordt gemaakt. Deze bepalingen ziju een ware weldaad voor de arbeiders, en vooral voor hunne vrouwen, die in het vervolg manlief in de kroeg zullen zien zitten. Een bijkomstig voordeel is, dat alle vergaderingen gehouden in de bovenlokalen van perceelen, warr beneden getapt wordt, vanzelf van alle drankgebruik vrij zullen zijn. De man die ze ontworpen heeft, toonde een even goede kennis te hebben van het menschenhart als van sommige eigenaardigheden van ons volksleven, en durrmede toegerust, deed hij eęn genialen greep. Mogen ziju voorstellen unaniem worden aangenomen! ') Terecht wordt in de Memorie van Toelichting opgemerkt dat reeds nu alle fatsoenlijke drinkgelegenheden een onbelemmerd inzicht van de straat af verleenen. Dit houde men in het oog, omdat er uit blijkt, dat het voorstel zoo radicaal niet is als door، sommigen uit eigenbelang wordt voorgesteld.

Hoewel men moet erkennen, dat 't moeilijk anders kon, is het toch jammer dat deze zoo gewenschte bepalingen zullen beperkt blijven tot nieuw op te richten drankgelegenheden, en dat er door Gedeputeerde Staten dispensatie van zal kunnen.worden verleend. Neemt men dit in aanmerking, dan schijnt het voorgestelde waarlijk niet draconisch.

Deze bepalingen zullen ook gelden voor drankgelegenheder, waar slechts wiju en bier wordt verkocht - terecht. Dat logementen, societeiten, restaurants en de "buitengewone inrichtingen voor : maatschappelijk verkeer" er van zulleu zijn vrij gesteld, vermelden wij reeds met leedwezen.

Niet minder toejuiching verdienen de bepalingen, krachtens welke de zoogenaamde "damesbediening" in drank- en bierhuizen verboden zal zijn. Het is niet noodig, daarover én woord meer te verliezen.

Onder de verboden lokmiddelen behooren ook hazardspelen (al weder valt het op, dat societeiten dnarvan vrij zijn!), maar niet biljarten. Daaromtreut loopen de meeningen uiteen. De

${ }^{1}$ ) Het V. V. geeft daarop helaas tot nog toe weinig uitzicht. 
Volksbond-Commissie en de heer van der Woude zien in het biljart een der gevaarlijkste middelen om jeugdige personen naar de kroeg te lokken. Het komt mij voor, dat zij over het hoofd zien, waarvan zij zich anders dagelijks in onze koffiehuizen kunnen overtuigen, dat de stilzwijgende $\mathrm{d}$ wang, om onder het biljarten te borrelen, waaraan het in mijn studententijd nog haast ondoenlijk was zich te outtrekken, rrijwel is opgeheven. Ik geloof dus, dat de Regeering terecht deze groote stoornis in de bestannde toestanden niet heeft willen aanbrengen, die ortstaan zou, wanneer men het biljart uit alle gelegenheden met vergunning verbande. Aan de andere zijple moet ik zeggen, dat ik gaarne den tijd zou beleven, dat een biljart, behalve bij particulieren, alleen te vinden zal zijn in een alkoholvrij lokaal.

Ook gelegenheden tot lichaamsoefeningen kuunen een vergunning hebben. Tooneelvoorstellingen zullen in gebouwen met vergunning alleen met bijzondere toestemming van Gedeputeerde Staten mogen gegeven worden, welke telkens voor vijf jaar verleend wordt. Twee vrijwel noodzakelijke concessies ann het bestaande.

Tot eenige concessie zag de Regeering zich ook genoopt betreffende de wachtkamers van spoorwegen en dergelijke. Hoezeer hier beperking van drankverkoop noodig was, toont zij in te zien, waar zij schrijft:

"Die kamers (van de stations nl.) toch zijn plaatsen, waar zoowel mannen, vrouwen als kinderen bij wijlen gedwongen zijn te vertoeven. Moet men nu eeuerzijds ieder vrijlaten sterken drank te gebruiken, indien hij dat wil, anderzijds valt het niet te loochenen, dat dit gebruik in de hier besproken inrichtingeu zijn zuiver individueel karakter verliest door de plaats, war, en de velen, in welker gedwongen tegenwoordigheid het geschiedt. De verleiding tot navolging is hier ongemeen sterk."

Zij meende echter een middenweg te moeten inslaan, die mij niet kwaad gevonden lijkt. In de stations zal drank niet meer te verkrijgen zijn in de gewone wachtkamers, maar uitsluitend in éen bepaald lokaal, door een drankbestrijder bij voorbaat "het jeneverhokje" gedoopt; en zelfs dat zal er niet mogen zijn, wanneer er geen andere wachtkamer is. Hierdoor zullen de volmaakt overbodige en schadelijke vergunningen in vele staţionnetjes van trams en buurtspoorwegen vervallen. 
Voortreffelijk is ook, dat alle drankverkoop zal gestaakt worden van 's avonds 11 tot 's ochtends 7 uur. Nog beter zou het zijn als dat nurtje van 11 uur ook tevens het sluitingsuur van het lokaal was. Zondags zal de verkoop tot 2 uur verboden zijn, een bepaling, die nu'reeds heel wat bestrijding heeft uitgelokt. Wij drankbestrijders, die zoo menigmaal hebben aangedrongen op een sluiting van Zaterdagavond tot Maandagochtend, gelijk in Noorwegen, en die een opengaan van de kroegen des ochtends om 7 uur nog rijkelijk vroeg vinden met het oog op den uaar żijn karrewei gaanden werkman, wij kunnen in deze bepalingen, die wij hartelijk toejuichen, nog slechts een minimum zien. Dnarentegen krijgen wij iets, dat wij ook lang gevragd hebben; op lotingsdagen en andere traditioneele drinkdagen zal de geheele verkoop kunnen worden verboden, hetzij in de geheele gemeente hetzij in gedeelten daarvan. Ik vrees echter, dat deze goede bepaling in de praktijk vrij waardeloos zal blijven, nu die bevoegdheid rerleend is ann den gemeenteraad, in wien maar al te raak invloeden werkzaam zijn, die nu juist niet met de strekking van dit wetsartikel strooken. Bovendien kan er un alleen van gebruik gemankt worden voor vaste, ieder jaar terugkeerende, dagen. Waarom kon die bevoegdheid niet gegeven worden aan den burgemeester, als hoofd der politie? -

Daarentegen is het juist gezien, dat in de voorgande alinea van hetzelfde artikel aan den gemeenteraad het recht is gegeven om ook op gewone dagen den drankverkoop nog verder te beperken, mits tot niet minder dan 8 uur per dag, en om het openingsuur op Zondag nog later te stellen dan 2 uur ${ }^{1}$ ) en om in gedeelten van gemeenten het aantal vergunningen beneden het wettig maximum te beperken tot nul toe, waardoor en betere repartitie der vergumningen over de gemeente mogelijk wordt gemaakt. Tot bevordering van hetzelfde doel zal het een

1) De hepalingen omtrent bet gewone sluitingsuur missen misschien de noodige plooibaarheid met het oog op plaatselijke toestanden. Zoil het niet eenvoudiger. zijn ze met de laatstbesprokene aldus te combineeren, dat bepaald werd, dat de gemeentejnad de openings- en slujtingsuren vaststelt, met dien verstande, dat de drankverkoop gedurende minstens 8 en hoogstens 16 achtereenvolgende uren per etmaal worde gestaakt en des Zondags niet vóór $2 \mathrm{n}$. des $\mathrm{n}$. m. mag aanvangen? 
vergunninghouder ook onder zekere voorwaarden toegestaan worden, zijn lokaliteit naar elders in de gemeente te verplaatsen. Deze bepaling heeft $\mathrm{m}$. i. ook het goede, dat zij den thans onverbreekbaren band tusschen het perceel en de vergunning opheft, en clus de kunstmatige waardevermeerdering althans eenigszins beperkt. De Volksbond-Commissie ziet er echter bezwanr in, en wil, dat-verplaatsing van vergunningen alleen zal kunnen geschieden met goedkeuring van de Kroon, op voorstel van B. en W., Gedeputeerde Staten gehoord.

Nog een bepaling is in het wetsontwerp opgenomen, waar wij, en het volk zelf, en allen, die het wel met hetzelve meenen, lang naar verlangd hebben, de bepaling, dat geen nitbetaling van loon mag geschieden in drankneringen, of in lokaliteiten, die daarmede binuenshuis gemeenschap hebben.

Daarentegen zijn wij eenigszins teleurgesteld door het bepaalde betreffende jeugdige personen (art. 15g). Omtrent dit gewichtige punt, dat in de beide wetsontwerpen-Borgesius eenvoudig geignoreerd werd, zegt de Memorie van Toelichting: "Geen actie tegen het alkoholkwaad kan voldoende slagen, als de dranklokalen vrijelijk openstaan voor. het opkomend geslacht. Een verbod is hier een daad van mantschappelijk behoud (lees: verweer.)" Derhalve stelt de Regeering voor, dat personen beneden de 16 niet zonder geleide van ouderen in de drankhuizen mogen worden toegelaten. Heel goed bedoeld, maar in drieërlei opzicht onvoldoende. Ten eerste is de leeftijdsgrens onoordeelkundig gekozen; op 16 jarigen leeftijd eindigt niet, maar begint juist voor de meeste jougelieden de gevaarlijkste tijd, waarin zij het meest aan verzoeking bloot staan en het eerst er voor bezwijken, de periode, waarin op meer dan één gebied de slechte gewoonten worden angeleerd, die later het gansche individu ondermijnen en het leven van hem en van de zijuen vergallen zullen. In de tweede plaats wreekt zich hier, gelijk wij reeds boven annmerkten, de leemte, dat de bier- en wijnverkoop niet in het systeem der wet is opgenomen. Aan de verleiding; die van bierhuizen en bodega's uitgaat, die eigenlijk voor haar zooveel erger is, laat de regeering onze jongelingschap onbeschermd blootstaan. In de derde plaats kunnen nu kinderen 
onder de 16 door een jongen van even over de 16 of door minder nauwgezette personen, die zich daartoe leenen, een drankhuis binnengeloodst en daar op bier getracteerd worden.

Met dezelfde verblijdende eenstemmigheid, die wij reeds meermalen mochten constateeren, wordt ook op dit punt door de beide drankwet-comités, thans geflankeerd door de Nederlandsche Onderwijzers-Propaganda-Club, annvulling der wet verzocht. De Nederlandsche Onderwijzers-Propaganda-Club en het Uitvoerend Drankwet-Comité vragen de leeftijdsgrens te verhoogen tot 18 jaar (en dan uatuurlijk ook voor de artikelen, die den verkoop van sterken drank an jeugdigen en het gebruiken van jeugdige werkkrachten in drankneringen verbieden), en om het verbod ook uit te strekken tot de gelegenheden, waar alleen gegiste dranken worden verkocht. Dit laatste verzoek wordt ook door de Volksbond-Commissie gesteund. De twee eerstgenoemde petitionarissen willen ook nog een bepaling opgenomen zien, die verbiedt an personen onder de 18 jaar, die onder geleide in het lokaal aauwezig ziju, alkoholhoudende dranken te verstrekken. Mij wil het voorkomen, dat er nog had moeten worden bijgevoegd de woorden: "zonder geleide van onderen "te vervangen door. "Zonder geleide van volwassenen." Vergis ik mij niet, dan bestanu voor openbare musea soortgelijke bepalingen.

Overigens verwijzen wij naar de nitnemende toelichting bij liet adıes aan de Tweede Kamer van de Nederlandsche Onderwijzers-Propagauda-Club.

\section{Bepalingig, Beoogende be'tere handhaving der We't en BES'IIJDING VAN DEN CLANDESTIENEN DRANKHEANDEL.}

Tudien er é́n punt was, warop om ni um consensu herriening en verscherping. der wet dringend noodig was, dan was het wel hare handhaving. Het was en is van algemeene bekendheid, dat zij schromelijk ontdoken en zeer slapjes uitgevoerd wordt. De Regeering zelf exkent het onomwonden en zij wil krachtige maatregelen nemen ter verbetering. Op dit punt, althans wat het eerste gedeelte betreft, vindt zij bij uitzondering juiet alleen de drankbestrijders, mar ook hun antagonisten, de drankverkoopers, op hare zijde. Zeer leerrijk is het citat, dat zij geeft uit bovenvermeld werk "Het dogma der Drankwet. Rekest aan de Tweede Kamer met Toelichting", (bl. 5 noot). Dat adres ging uit 
van : bierbrouwers, distillateurs, likeurstokers, handelaren in sterke dranken in het groot en in het klein enz. In de toelichting komt het volgende voor ter beantwoording van de vrag, wie bijv. in Amsterdam zijn de slijters boven $2 \mathrm{~L}$. (het maximum voor een verkoop in het klein volgens de bestrande wet). "Wel, dat zijn in Amsterdam de ruim duizend clandestiene tappers, die zich noemen bierhuishouder-slijter, d. w. z. verkooper van sterken drank boven de $2 \mathrm{~L}$. Werkelijke slijters boven $2 \mathrm{~L}$., die niet beneden $2 \mathrm{~L}$. verkoopen, zijn er in Amsterdam niet. De groote slijters, zoowel in andere steden als in Amsterdam, hebben allen vergunning en verkoopen ook allen bij de kleine maat, of wel zij verkoopen c!nndestien. Men meene namelijk vooral niet, dat clandestiene verkoopers alleen onder de kleine luiden te vinden zijn; zij zijn evenzeer en in even grooten getale te vinden onder de grootere verkoopers, zoonls grossiers in gedistilleerd, de wijukoopers, de depôthouders van -die grossiers in gedistilleerd en van die wijnkoopers, de groote restaurateurs euz". Dat heeft de regeering zich vour gezegd gehouden. Zij citeert nog een voorbeeld van een gemeente, wanr het debiet van de meeste neringen niet gaat boven $1600 \mathrm{~L}$. ad 50 pCt. en waar een vergunning zonder nering bekend is, die in 1901 een debiet had $\operatorname{van} 1163 \mathrm{~L}$. ad $50 \mathrm{pCt}$.

Als men vraagt, hoe zulke toestanden mogelijk ziju, dan moet geantwoord worden, dat niet alleen de opvattingen, die omtrent deze zaken zoowel bij de direct belanghebbenden als bij een groot gedeelte van het publiek en bij de organen der rechterlijke en der uitvoerende macht in omloop waren, daaraan schuld hebben gehad, maar ook de omstandigheid, dat de wet de overheid slechts in zeer onvoldoende mate tegen wetsovertredingen wapende. Zoo heeft de Hooge Rard uitgemankt, dat ongeoorloofde verkoop van sterken drank in het klein slechts dan strafbar was volgens de wet, wanneer de a anwezige hoeveelheid minder was dan $2 \mathrm{~L}$. Dat beteekent zooveel als volslagen straffeloosheid. Daarbij was het den handhavers van het gezag haast onmogelijk: gemaakt drankwetovertredingen te constateeren, vooral daar men in ieder bijzonder geval er terstond bij was met het geroep van "provocatie". Eindelijk, de straffen, waartoe de overtreders veroordeeld werden, waren, hetzij dan al of niet in overeenstemming met de letter en den geest van 
de wet, veel te licht, en stonden in geen verhouding tot het geldelijk voordeel, dat aan overtreding verbonden was.

Op al deze punten wil de wet verbetcring aanbrengen, en zal zij dat ongetwijfeld kunnen doen.

In de eerste plaats, daar de grootste. wetsovertreders en clandestiene drankverkoopers gebleken zijn de slijters en de houders van drankgelegenheden zonder vergunning, zoo worden de slijters, zooals boven reeds in een ander verband is medegedeeld, aan een vergunning gebonden en aan beperkende bepalingen onderworpen. In verband daarmede wordt het minimum van verkoop van sterken drank in het klein van 2 L. gebracht op 10 L. De regeering wijst er op, dat in het oorspronkelijk ontwerp van 1881 stond 5 , en dat in Noorwegen de oudervinding gevoerd heeft tot een geleidelijke verhooging vau het maximum tot $40 \mathrm{~L}$. - een beteekenisvolle vingerwijzing!

In de tweede plaats zullen de houders van gelegenheden tot het gebruik ook van niet-gedistilleerde dranken niet meer an zichzelf overgelaten zijn. Zij zullen om hun nering te kunwen uitoefenen een "verlof" noodig hebben, dat wel kosteloos zal verkrijgbaar ziju, maar slechts op voorwaarden, die in hoofdzaak overeenstemmen met de eischen, die voor vergunninghouders en hume lokaliteiten gesteld zijn. Zij komen daardoor ook te staan onder de contrôle der wet en vau hare uitroerders, incluis het goedgezinde publiek, en worden onderhevig aan hare straften.

Daarbij wordt onderscheiden tusschen een verlof tot verkoop van gegiste en van niet-alkoholhoudende dranken. Op deze laatsten zijn de bepalingen, dat de lokalen gelijkvloers moeten liggen en men er van buiten moet kunnen inzien, niet toepasselijk. Zooals de toestand op het oogenblik is, schijnt dit juist gezien; maar wanneer men bedenkt, dat al deze bepalingen moeten dienen om den clandestienen drankverkoop te fnuiken, dan zie ik geen reden, waarom een zich noemend geheelonthouderskoffiehuis anders zou worden behandeld dan een bierhuis of bodegr. De echte geheelonthouderskoffiehuizen zullen er niets tegen hebben onder dezelfde contrôle geplaatst te worden, te meer, daar de wet de gelegenheid openlaat voor alle "te goeder trou w" bestaande iurichtingen, om van alle bepalingen van dien aard, die hen noodeloos zouden belemmeren, dispensatie te krijgeu. 
Dat de slijters geen verlofbrief zullen krijgen, stipten wij reeds ån; voor de tappers daarentegen is hij overbodig.

De houders van een verlof voor den verkoop alleen van alkoholvrije dranken mogen geen gegiste dranken in voorraad hebben, en wie geen vergunning heeft, mag heelemaal geen sterken drank in zijn lokaliteit in voorraad hebben. De zooeven medegedeelde en eenige dergelijke wetsinterpretaties van den Hoogen Raad worden door deze en andere redactieverbeteringeu onmogelijk gemaakt.

En nu de contrôle. Die wordt op verschillende wijze verscherpt. Alle ambtenaren, belast met het opsporen van overtredingen der wet, zullen niet alleen ten allen tijde toegang hebben tot de localiteiten met vergunning of verlof, maar zij zullen ook beslag kunnen leggen op alles wat "redelijkerwijze vermoed kan worden gediend te hebben of bestemd te zijn geweest tot het plegeu eener overtreding." Het bewijsmateriaal tegen overtreders wordt hierdoor belangrijk uitgebreid, ja eigenlijk eerst geschapen.

Bovendien -- en dat is een der gewichtigste bepalingen der wet - wordt de kring dier ambtenaren uitgebreid met afzonderlijke ambtenaren ad hoc, inspecteurs en adjunct-inspecteurs, belast met het toezicht op de naleving der wet in het algemeen. Zij worden door de Kroon benoemd, die ook hun instructie vaststelt.

Met de instelling dezer drankwet-inspectie wordt een lang gekoesterde wensch der drankbestrijders vervuld. In verband met de vele verbeteringen, die in de drankwetsrechtspleging worden aangebracht mag men van hare werking de beste verwachtingen koesteren.

De regeering heeft bovendien gemeend de goedgezinde burgerij zelf tot medewerking in het handhaven der wet te moeten oproepen. Op voorbeeld blijkbaar van de commissies tot wering van schoolverzuim, die door de leerplichtwet in het leven zijn geroepen, stelt zij voor in iedere gemeente van meer dan 10000 iuwoners éen of meer commissies van meerderjarige ingezetenen te benoemen, mede belast met het toezicht op de naleving der wet.

Het voorstel ziet er op het eerste gezicht wel sympathiek uit maar het is toch de vraag of het niet beter was het politietoezicht aan de politie over te laten en niet burgers onderling daarmede te belasten. Bij de bestrijding van 't schoolverzuim was 
't een gansch ander ding, omdat daar sterk met het middel van persuasie gewerkt wordt.

Hoe dit zij, het voorstel heeft in veler oog veel van zijn aantrekkelijkheid verloren, omdat de regeering de vrouw uitdrukkelijk van het lidmaatschap dezer commissies uitsluit. Te vergeefs gist men naar de reden van die uitsluiting. Men zou zoo zeggen, zoo ergens, dan is de vrouw in deze commissies op haar plaats, van welke de regeering zoo terecht zegt: dat "hare waarde uitsluitend bepald zal worden door de waarde harer ledeu." Heeft de regeering wel bedacht, dat uit deze woorden kan worden afgeleid, dat zij de vrouw als een minderwardig wezen beschouwt? In alle landen is tot nog toe de medewerking van de vrouw van het allergrootste belang gebleken voor de bestrijding van het drankeuvel, en dat is warrlijk geen wonder, wamneer men bedenkt, hoezeer de vrouw daarbij geinteresseerd is. Moge deze hatelijke uitsluiting, waartegen ook de Volksbond-Commissie heeft geprotesteerd, nog voordat de wet in openbare behandeling komt daaruit verdwijnen!

Vermoedelijk zal in de instructie der inspecteurs wel worden opgenomen, dat zij ambtshalve toegang hebben tot deze commissies. De heer van der Woude wijst er echter op, dat het wenschelijk is, dat de rechten en bevoegdheden dezer rijksambtenaren hun grond vinden in de wet zelf. Worden bepalingen daaromtrent in de wet zelf opgenomen, dan acht hij die commissies uit de burgerij, omtrent wier werking hij zich vrij sceptisch uitlaat, overbodig.

Findelijk bevat de wet nog eenige verstandige overgangsbepalingen, wier opsomming de lezer ous zeker wel schenken zal.

\section{SLO'WOoRd.}

Zoo zijn wij dan gekomen aan het einde van ons overzicht, waarbij wij geen enkel wezenlijk punt meenen overgeslagen of in het duister gelaten te hebben.

Onze bespreking zal ongetwijfeld den indruk gewekt of versterkt hebben, dat deze wetsvoordracht een ware aubaine is voor alle drankbestrijders ex professo, van welke kleur of nuance overigens ook. Wat zij er in missen of afkeuren, is op één punt na: de uitzonderingsbepalingen voor Sociteiten, die 
hun absuluut onduldbaar voorkomen — betrekkelijk onbeduidend vergeleken met wat zij als winst meenen te kunnen boeken. Hun aller vurige wensch is dan ook, dit wetsontwerp, kan het zijn nog in hun zin geamendeerd, maar in ieder geval niet door ongelukkige amendementen verzwakt en verwaterd, in het Stantsblad te zien verschijnen.

Toch zou ik niet gaarne den lezer, die mij zoolang welwillend gehoor heeft verleend, onder den indruk naar huis willen laten gaan, alsof deze wet nu eigenlijk voor het speciale plezier van de professioneele drankbestrijders de wereld werd ingezonden. Wordt deze $d$ waze onderstelling, gesteld dat iemand ze maakte, reeds door de namen der beide onderteekenaren vall de wetsvoordracht gewraakt, de zaak is er veel te ernstig voor om ze te opperen bij wijze van stemming-maken tegen de wet. De regeering spreekt het telkens en op allerlei wijze uit: herziening en verscherping van de drankwet, verhoogde actie van de natie tegen den drankduivel ook door middel van hare overheden en rechtspraak, is een dringende eisch des tijds, is een eminent volksbelang.

Zoo min als de politiek er iets mede te makeu heeft, zoo min de wenschen of bezwaren van enkele groepen van ingezetenen. De Regeering meent, dat de natie zelf nar verlossing van de drinkgewoonten en hun nasleep begeerig is; en wij met haar. Zij beroept zich herhaaldelijk op de gewijzigde opvattingen daaromtrent, en wij meenen terecht. De aanneming van deze wet door de beide takken der volksvertegenwoordiging zal het bewijs zijn, dat zij zich niet heeft vergist.

Schrijver dezes is geen anhanger der tegenwoordige regeering en geen bewonderaar van haar politiek. Maar hij meent, en hij acht het een plicht der eerlijkheid dit openlijk uit te spreken, dat zij door deze voordracht getoond heeft, dat het iets meer dan een ijdele leus of woordenspel is, wanneer zij zegt voor de zedelijke belangen der natie te willen waken en die zooveel mogelijk ook door de wetgeving te willen bevorderen. Hij meent, dat men haar hiervan akte verschuldigd is, en dank en hulde, en dat alle weldenkenden deswegen geroepen zijn haar in dit haar streven oprechtelijk te steunen.

Amstèrdam, December $1903 . \quad J$. H. Gunning Wż. 